\title{
The early middle Miocene lacustrine gastropod fauna of Džepi, Bosnia and Herzegovina (Dinaride Lake System): high endemism in a small space
}

\author{
Thomas A. Neubauer, Oleg Mandic \& Mathias Harzhauser
}

\begin{abstract}
This contribution constitutes a taxonomic and systematic revision of the lacustrine gastropod fauna of the locality Džepi in the Prozor Basin (Bosnia and Herzegovina). 15 gastropod species were detected in the course of the present study, belonging to the families Neritidae, Melanopsidae, Hydrobiidae, Pachychilidae and Planorbidae. The fauna revealed a high degree of endemism (66.6\%) and low biogeographic relationships to coeval middle Miocene faunas of the Dinaride Lake System (DLS; maximum of shared species 14.3\%). None of the species has been documented from outside the DLS. The generic composition with abundant melanopsids and hydrobiids but rare pulmonates is typical among DLS faunas and characteristic of shallow long-lived lakes. Since a large part of the type material of former investigations is lost, we designate five neotypes to settle the taxonomic status of the respective species. In addition, five lectotypes are defined from existing syntype series. Based on the occurrence of the biostratigraphical marker species Illyricocongeria cf. aletici (Brusina, 1907) (Bivalvia: Dreissenidae) and faunal similarities to the Kupres Basin the deposits are classified into the early Langhian ( ca 15.3-15.0 Ma). Illyricella gen. nov. and Illyricella dzepiensis gen. nov. sp. nov. (Truncatelloidea: Hydrobiidae) are introduced as new, endemic taxa. $\bullet$ Key words: freshwater gastropods, taxonomy, systematics, endemic fauna, neotypes, lectotypes, Illyricella dzepiensis gen. nov. sp. nov.
\end{abstract}

Neubauer, T.A., MAndiC, O. \& HARZhauser, M. 2016. The early middle Miocene lacustrine gastropod fauna of Džepi, Bosnia and Herzegovina (Dinaride Lake System): high endemism in a small space. Bulletin of Geosciences 91(2), 271-296 (8 figures, 1 table). Czech Geological Survey, Prague. ISSN 1214-1119. Manuscript received August 28, 2015; accepted in revised form March 10, 2016; published online May 19, 2016; issued June 30, 2016.

Thomas A. Neubauer (corresponding author), Oleg Mandic \& Mathias Harzhauser, Geological-Paleontological Department, Natural History Museum Vienna, Burgring 7, 1010 Vienna, Austria; thomas.neubauer@nhm-wien.ac.at, oleg.mandic@nhm-wien.ac.at, mathias.harzhauser@nhm-wien.ac.at

The lacustrine mollusks of Džepi belong to the fauna of the so-called Dinaride Lake System, a compound of several early to middle Miocene freshwater lakes within the Dinaride Mountains (Fig. 1; Krstić et al. 2003; Harzhauser \& Mandic 2008; Mandic et al. 2009, 2011; De Leeuw et al. 2012; Neubauer et al. 2015a, c). The deposits of the paleo-lakes cover large parts of today's Bosnia and Herzegovina, Croatia, SW Serbia and NW Montenegro. Many of the faunas are well resolved by numerous taxonomic works (Neumayr 1869, 1880; Brusina 1870, 1872, 1874, 1876, 1878, 1881, 1882, 1884, 1896, 1897, 1902, 1907; Bourguignat 1880; Kochansky-Devidé \& Slišković 1978; Jurišić-Polšak 1979, 1984; Žagar-Sakač 1981, 1986, 1987 , 1990; Žagar-Sakač \& Sakač 1984; Jurišić-Polšak et al. 1993; Bulić \& Jurišić-Polšak 2009; Harzhauser \& Mandic 2010; Neubauer et al. 2011, 2013a, b, 2014b, 2016; Krstić et al. 2013). However, only two of them deal with species from Džepi. The first taxonomic investigation dates back to Neumayr (1880), who listed one bivalve and four gastro- pod species, latter of which were all new to science. The second work including species from Džepi is the comprehensive monograph of Brusina (1902), who introduced and illustrated eleven new species from that locality. Other works mentioning mollusks from that region are the geological overviews by Bittner (1880, 1887) and Katzer (1921), who documented several of the taxa described by Neumayr (1880) as well as remains not identified at the species level. Finally, Wenz (1923-1930) summarized all the occurring gastropod species in his comprehensive Fossilium Catalogus. Apart from that, no other taxonomic study treating Miocene freshwater species from that area exists.

Few of the occurring species have been properly described and illustrated as yet. While Neumayr (1880) provided short discussions and few illustrations, Brusina (1902) only supplied figures. Unfortunately, all the original material from Džepi studied by Neumayr (1880) and several type specimens of Brusina (1902) are lost. The present investigation therefore aims at a taxonomic and 


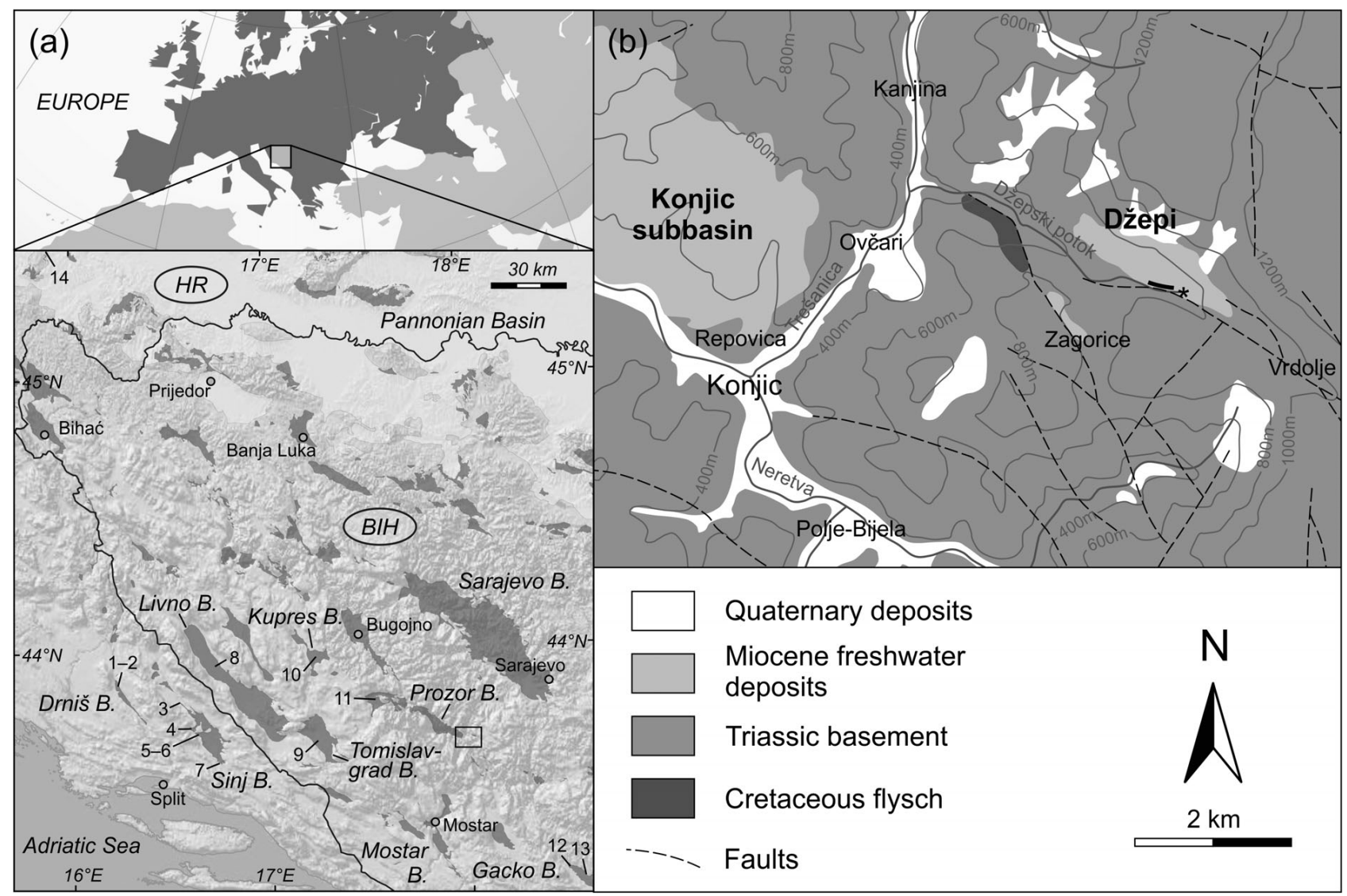

Figure 1. Geographical and geological overview of Džepi and the Prozor Basin in the context of surrounding Dinaride Lake Systems basins. (a) Distribution of basins of the Dinaride Lake System (dark grey), with indication of localities mentioned in the text: 1 - Miočić, 2 - Parčić, 3 - Ribarić, 4 - Lučane, 5 - Župića potok, 6 - Trnovača, 7 - Strmendolac (Crveni klanac), 8 - Čelebić-Jaruga, 9 - Šuica gaz, 10 - Fatelj, 11 - Podbor-Šćit, 12 - Gračanica, 13 - Vrbica, 14 - Dugoselo. (b) Geological sketch of the Džepi area (modified after Mojićević \& Laušević 1971, Jovanović et al. 1977, Sofilj \& Živanović 1979, Mojićević \& Tomić 1982). The asterisk marks the location of sample "Džepi 1"; the bar next to it indicates the approximate position of the section studied by Katzer (1921).

systematic revision, pending since the last listing by Wenz (1923-1930), including descriptions, discussions and illustrations of the available type material, old collections and newly collected material. We designate neotypes to settle the taxonomic status of five species for which the type material is lost. Moreover, we define five lectotypes from still existing syntype series.

\section{Geological setting}

There is little published data about the depositional history of the Miocene sediments at Džepi (also known as Džepe or Žepy). Information about the sediment distribution and surrounding geological units derives from Bittner (1880), Katzer (1921) and geological maps (Mojićević \& Laušević 1971, Jovanović et al. 1977, Sofilj \& Živanović 1979, Mojićević \& Tomić 1982).

The freshwater Miocene around Džepi is restricted to a very small area of $1.97 \mathrm{~km}^{2}$ (calculated with ESRI ArcGIS
10.0 using Behrmann projection), encompassed by a basement of Triassic limestones and dolomites (Fig. 1). Details about the sedimentary succession are provided by Bittner (1880) and Katzer (1921). Both authors report a sequence of whitish, greenish-grey, brownish to bluish marls and sandstones interspersed with 3-4 thin lignite seams with a maximum thickness of $70 \mathrm{~cm}$ each. The section at the Mali potok at the northern slope of Mt. Golišan (Fig. 1) described by Katzer (1921) starts with bluish-grey clay of unknown thickness, followed by a $40 \mathrm{~cm}$-thick coal seam. Upsection follows a 2 m-thick greenish-grey fine marl, a $70 \mathrm{~cm}$-thick coal seam, $1.2 \mathrm{~m}$ of grey clayey marls, $20 \mathrm{~cm}$ coal schists, $10 \mathrm{~cm}$ coal, $8 \mathrm{~cm}$ marls, $15 \mathrm{~cm}$ coal, and finally grey-yellow limy marls, forming the top of the section. The beds are dipping with $28^{\circ}$ towards northeast, while in the northern part of the small basin the layers dip towards southwest, forming a shallow syncline. The here studied gastropods are contained in both the coals and marls, but are particularly well preserved in the fine-grained marls. After Katzer (1921), the most common fossils are the 
gastropods Melanopsis mojsisovicsi (Neumayr, 1880) and Marticia tietzei (Neumayr, 1880).

More detailed assessments of the paleogeographic situation and biostratigraphic classification and its relation to the deposits from the Prozor Basin are outlined in the discussion.

\section{Material and methods}

We studied the available type material stored at the Croatian Natural History Museum in Zagreb (NHMZ) and the Austrian Geological Survey in Vienna (GBA). Additional material is present from the rich collection of the Natural History Museum Vienna (NHMW; coll. No. 2014/0364/0001-0041), including several hundred specimens in total. One sample yielding several tens of shells was collected by the authors and is referred to as "Džepi 1" (Fig. 1; GPS/WGS84: 43 40 05.5" N, 1801' 38.1" E); the material is stored at the NHMW as well. Specimens were cleaned where necessary with an ultrasonic device. The SEM images of the types stored at the NHMZ were made with a Tescan TS5136MM; those of material of the NHMW were made with the on-site JEOL JSM-6610LV. The macro-photographs were made with a ZEISS Discovery.V20 stereomicroscope with attached AxioCam MRc5 using the stacking module of the software ZEISS AxioVision SE 64 4.9.

\section{Systematic paleontology}

Below, we designate five neotypes to settle the taxonomic status of the respective species for which the original material is lost. These five species were described by Neumayr (1880) and Brusina (1902). Neumayr's material has been stored in the collection of the GBA, which was partly destroyed during World War II. Brusina's collection at the NHMZ is in a good condition and well organized (Milan et al. 1974), but several types are missing. Despite considerable effort to locate the specimens in the NHMZ collection, they could not be found. Although Brusina regularly sent material to colleagues at other institutions, there is no single case known where he sent syntypes.

The systematic arrangement follows Bouchet \& Rocroi (2005), Wade et al. (2006), Jörger et al. (2010), Criscione $\&$ Ponder (2013) and the FreshGEN database (Neubauer et al. 2014c).

Class Gastropoda Cuvier, 1795

Subclass Neritimorpha Golikov \& Starobogatov, 1975

Order Cycloneritimorpha Frýda, 1998

Superfamily Neritoidea Rafinesque, 1815

Family Neritidae Rafinesque, 1815

Subfamily Neritininae Poey, 1852

\section{Genus Theodoxus Montfort, 1810}

Type species. - Theodoxus lutetianus Montfort, 1810 [currently considered as a synonym of Theodoxus fluviatilis (Linnaeus, 1758)]. Recent; Europe. Type by original designation.

\section{Theodoxus reiseri (Brusina, 1902)}

Figure 2A-F

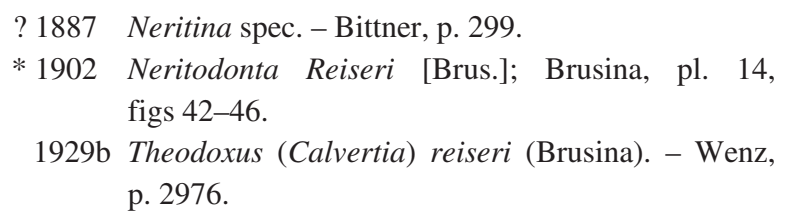
figs 42-46.

1929b Theodoxus (Calvertia) reiseri (Brusina). - Wenz, p. 2976.

Material. - 3 specimens from NHMW 2014/0364/0001; 9 specimens from GBA 2008/265/0097, GBA 2014/010/0001, GBA 2014/010/0004.

Type material. - The type material, including all specimens studied by Brusina (1902) (= syntypes), is lost. Despite considerable effort to locate the material, the syntypes could not be found. In order to bring stability to the nomenclature of this species and clarify its taxonomic status, we define a neotype from material of the type locality. There is no doubt that the neotype is conspecific with $T$. reiseri, as it fully matches the illustrations of Brusina (1902).

Neotype. - GBA 2014/010/0001 (Fig. 2A-C); height: $5.0 \mathrm{~mm}$, width: $5.5 \mathrm{~mm}$.

Type locality. - Džepi, Federation of Bosnia and Herzegovina, Bosnia and Herzegovina.

Type stratum. - Early middle Miocene (Langhian; Badenian) coal-limestone beds of the Prozor Basin.

Additional measurements. - Height: $5.3 \mathrm{~mm}$, width: 5.7 (Fig. 2D-F); height: $6.5 \mathrm{~mm}$, width: $6.7 \mathrm{~mm}$.

Diagnosis. - Small neritid with three angulations on last whorl, two of which form strong keels usually bearing marked excrescences. Aperture exposing massively thickened callus pad.

Description. - Small, glossy shell comprising up to 2.5 whorls. Apical region usually white, flattened, immersed, fully enclosed by last whorl. Shell typically bears three spiral angulations: one slightly below upper suture, one around mid-height of whorl, one close to base; whorl portions above and in between weakly concave. Base weakly convex. Lower two angulations usually amplified by marked, rounded keels, each of which bears around 6-7 strong, 


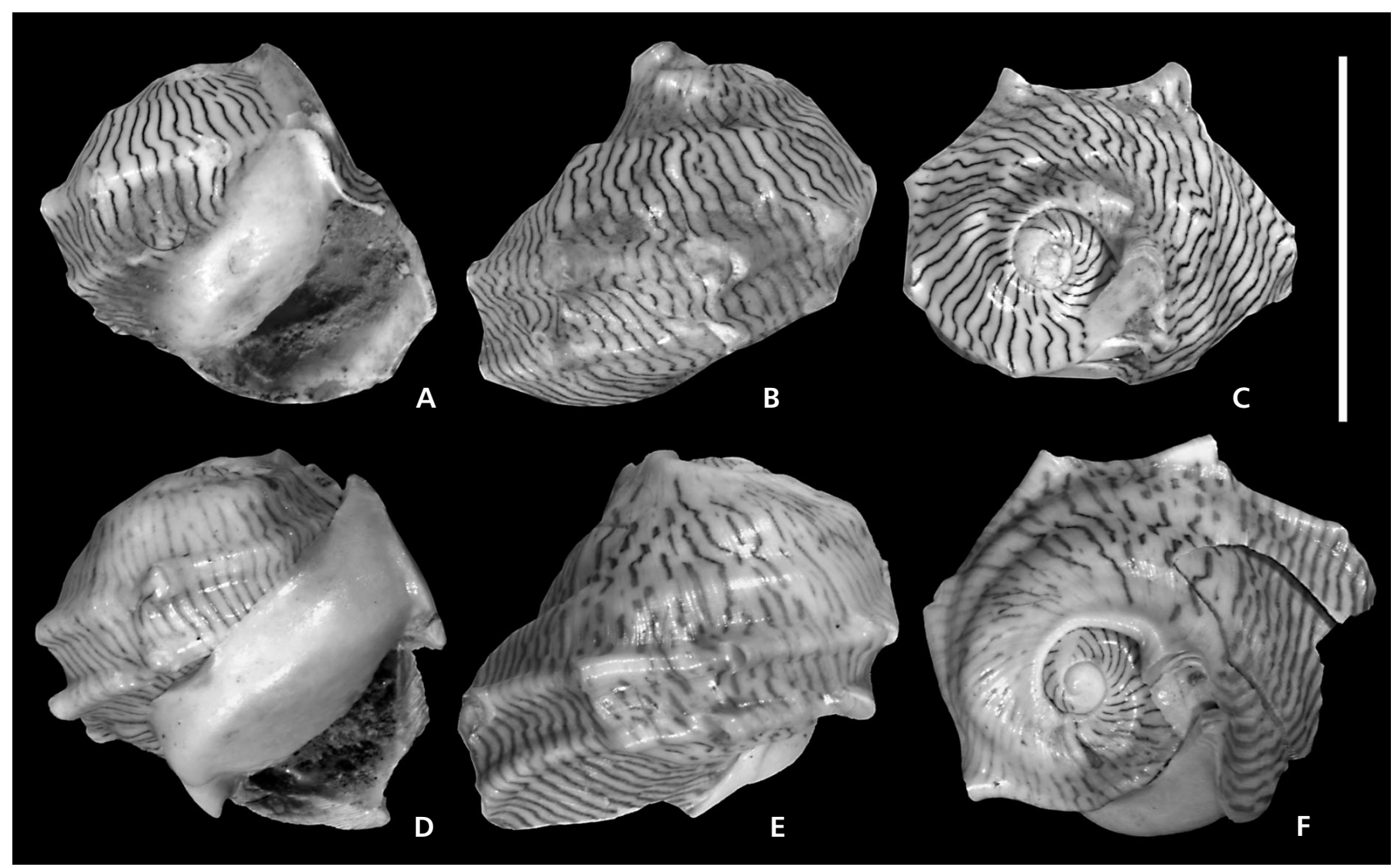

Figure 2. Neritidae. • A-C - Theodoxus reiseri (Brusina, 1902). Neotype, GBA 2014/010/0001. • D-F - Theodoxus reiseri (Brusina, 1902). GBA 2014/010/0004. Both specimens from Džepi. Scale bar corresponds to $5 \mathrm{~mm}$.

irregular excrescences per whorl. Excrescences point in growth direction, giving buzzsaw-like appearance from above. Sometimes excrescences are entirely absent; in a single specimen also keels were reduced to weak angulations. In latest ontogeny upper suture bulges out in apical direction, while remaining shell margin continues normal growth; this produces strong adapical indentation. Aperture widely semilunar, with sharply edged peristome and massively thickened, white, glossy callus pad. Coloring often preserved as densely spaced, light or dark brown, slightly wavy axial lines; occasionally lines are stronger undulating, produce zigzag lines, or form delicate, bifurcated pattern.

Discussion. - The peculiar morphology of T. reiseri prevents confusion with any other neritid species. The combination of angulation and tubercles on the last whorl is only found in T. imbricatus (Brusina, 1878) from the Kupres Basin. However, in that species the angulations never form offset keels and the tubercles are broader and stronger. Moreover, the callus is regularly semicircular in that species.

Occurrence. - Endemic to the Prozor Basin (Džepi) (Brusina 1902, Wenz 1929b).
Subclass Caenogastropoda Cox, 1960

Superfamily Cerithioidea Fleming, 1822

Family Melanopsidae H. Adams \& A. Adams, 1854

Subfamily Melanopsinae H. Adams \& A. Adams, 1854

\section{Genus Melanopsis Férussac in Férussac \& Férussac, 1807}

Type species. - Melania costata Olivier, 1804. Recent; Europe. Type by subsequent designation by Gray (1847).

\section{Melanopsis angulata Neumayr, 1880}

Figure 3A-F, I

* 1880 Melanopsis angulata n. f.; Neumayr, p. 479, pl. 7, fig. 8.

1887 Melanopsis angulata Neum. - Bittner, p. 299.

1929a Melanopsis angulata Neumayr. - Wenz, p. 2657.

non 2013a Melanopsis angulata Neumayr, 1880. - Neubauer $e t$ al., p. 132, figs 4a, b.

Material. - 51 specimens from NHMW 2014/0364/0001, NHMW 2014/0364/0010, NHMW 2014/0364/0012, NHMW 2014/0364/0014, NHMW 2014/0364/0015. 
Type material. - The only specimen studied by Neumayr (1880) is lost. Despite considerable effort to locate the material, the specimen could not be found. In order to clarify the taxonomic status of the species, we define a neotype from material of the type locality. We designate a more typical representative of this species as neotype than the one illustrated by Neumayr (1880), which shows an exceptionally broad shell. Facing the variability of this species at Džepi, there is no doubt that the neotype is conspecific with the lost syntype.

Neotype. - NHMW 2014/0364/0012 (Fig. 3A-C); height: $8.8 \mathrm{~mm}$, width: $4.8 \mathrm{~mm}$.

Type locality. - Džepi, Federation of Bosnia and Herzegovina, Bosnia and Herzegovina.

Type stratum. - Early middle Miocene (Langhian; Badenian) coal-limestone beds of the Prozor Basin.

Additional measurements. - Height: $8.9 \mathrm{~mm}$, width: $4.9 \mathrm{~mm}$ (Fig. 3E, F); height: $9.5 \mathrm{~mm}$, width: $5.5 \mathrm{~mm}$ (Fig. 3D, I).

Diagnosis. - Small deltoid melanopsid with row of few but marked spiny knobs close to lower suture, often connected by weak spiral keel, producing typically angular radial cross-section.

Description. - Small deltoid shell with up to seven straight-sided whorls. Shape ranges from very slender (as the neotype) to stout (as the lost holotype), including all kinds of intermediates. Already on early teleoconch whorls weak swellings occur, which become stronger during ontogeny and form spiky nodes to tubercles on last whorl. Nodes may be connected via weak spiral keels, resulting in angular radial cross-section (trigonal to pentagonal, partly depending on individual age). Nodes are located close to lower suture; course of upper suture of following whorl irregular where it overgrows nodes. At last whorl, which attains $65-70 \%$ of shell height, nodes are located on about mid-height. Aperture narrow, with thickened callus and columellar fold, which is weak at peristome but distinct and thin inside. Broad fasciole present. Coloring often preserved as axial, densely spaced, thin, dark yellow, zigzag or wavy lines.

Discussion. - The species is characterized by a near perfectly deltoid shape with straight-sided whorls passing into each other, an angular radial cross-section and a row of spiky nodes. The drawings in Neumayr (1880) are to some extent misleading, as they show an exceptionally broad specimen (being the only one available to Neumayr). Most of the studied individuals are much slenderer. As both mor- phologies are linked via intermediates and correspond in all other details, they are considered to belong to the same species.

Melanopsis angulata differs from $M$. pentagona Brusina, 1892 from the late Miocene of Markuševec in Zagreb (Croatia), which exhibits a second, weaker row of nodes (also connected via keels). Neubauer et al. (2013a) misidentified a species from the Kupres Basin with $M$. angulata. Those specimens have two rows of nodes, connected over weak axial riblets and lack the angular cross-section. At present we are not aware of a species name fitting to that morphology.

Occurrence. - Endemic to the Prozor Basin (Džepi) (Neumayr 1880, Wenz 1929a).

\section{Melanopsis carusi (Brusina, 1902) Figure 4A-D}

1880 Melanoptychia Bittneri n. f.; Neumayr, p. 480, pl. 7, fig. 11 [non Melanopsis Bittneri Fuchs, 1877].

1880 Melanoptychia Bittneri Neum. - Bittner, p. 418.

1887 Melanoptychia Bittneri Neum. - Bittner, p. 299.

1902 Melanoptychia Bittneri Neum. - Brusina, pl. 29, figs 27, 28 [non Melanopsis Bittneri Fuchs, 1877].

* 1902 Melanoptychia Carusi [Brus.]; Brusina, pl. 30, figs 6, 7 .

non 1902 Melanopsis Bittneri Brus. - Brusina, pl. 7, figs 18-21 [= Melanopsis cvijici Brusina, 1902].

1929a Melanoptychia bittneri Neumayr. - Wenz, p. 2869 [partim; not regarding Melanopsis Bittneri Brusina, = Melanopsis cvijici Brusina, 1902].

1929a Melanoptychia carusi Brusina. - Wenz, p. 2870.

2013a Melanopsis medinae nom. nov.; Neubauer et al., p. 135 , figs $5 \mathrm{a}-\mathrm{d}$.

Material. - 3 from NHMW 2014/0364/0007; 27 from GBA 2008/021/0436, GBA 2009/026/0021, GBA 2014/010/0002.

Type material. - The original type material of Brusina (1902) is lost. Despite considerable effort to locate the material, the syntypes could not be found. Consequently, we herewith define a neotype from material of the type locality to clarify the species' taxonomic status. The neotype matches the illustrations of Brusina (1902) fully, regarding details of the aperture, including the strong fold and prominent fasciole, the prominent ribs with weak nodes and the partly wavy suture. The only difference is the more convex last whorl in Brusina's illustration, which, however, might be a result of poor drawing; no such specimen is detected in the available material. 
Neotype. - GBA 2014/010/0002 (Fig. 4A, B); height: $9.8 \mathrm{~mm}$, width: $5.1 \mathrm{~mm}$.

Type locality. - Džepi, Federation of Bosnia and Herzegovina, Bosnia and Herzegovina.

Type stratum. - Early middle Miocene (Langhian; Badenian) coal-limestone beds of the Prozor Basin.

Additional measurements. - Height: $10.15 \mathrm{~mm}$, width: $6.50 \mathrm{~mm}$ (Fig. 4C, D).

Diagnosis. - Ton-shaped to ovoid shell with strong sigmoidal ribs bearing two rows of weak nodes below the suture; aperture with prominent columellar fold oriented perpendicular to the inner lip and broad, sharply edged fasciole.

Description. - Conical to slightly ovoid, highly sculptured shell, consisting of up to nine whorls. Shape variable, ranging from stout and almost globose to fairly slender. Whorl outline roughly rectangular to slightly trapezoid, producing step-like outline; impression enhanced by ornamentation, expressed as strong axial ribs with two rows of small rounded nodes below upper suture. Upper row occasionally produces wavy suture. Lower row always weaker; in some specimens entirely absent. Last whorl attaining about two-thirds of total height. Aperture bears massively thickened, sometimes angular callus pad and broad, sometimes sharply edged columellar fold, which is oriented perpendicular to the inner lip. Outer lip thin. Siphonal canal short, broad, recurved towards neck, producing broad, sharp fasciole.

Discussion. - Neubauer et al. (2013a) introduced M. medinae as replacement name for the secondary homonym $\mathrm{Me}$ lanoptychia bittneri Neumayr, 1880 [non Melanopsis bittneri Fuchs, 1877] described from Džepi. At that time, these authors were not aware of the morphologically extremely similar "Melanoptychia" carusi Brusina, 1902, likewise from Džepi. A comparison of material of that species stored at the NHMZ and the illustrations in Brusina (1902, pl. 30, figs 6, 7) with the illustrations of " $M$. bittneri" in Neumayr (1880) proved that both are nearly identical. Therefore, we consider both species synonymous, which makes $M$. carusi the first available name and $M$. medinae its junior synonym (ICZN 1999, Art. 60.2). The type material of $M$. bittneri, including all specimens studied by Neumayr (1880), is unfortunately lost.
As shown by Neubauer et al. (2013a; under the name M. medinae), this species exposes a considerable degree of morphological variability, particularly regarding its general shape. The specimen illustrated by Brusina (1902) represents a stouter form, while the presently available specimens are slenderer. Those slender specimens remind of $M$. cvijici but differ in the presence of nodes on the ribs and the presence of a columellar fold. Also, the ribs of $M$. cvijici are broader and slightly oblique.

For a discussion on the status of the genus Melanoptychia Neumayr, 1880 as synonym of Melanopsis see Neubauer et al. (2014a).

Occurrence. - Kupres Basin (Fatelj) and Prozor Basin (Džepi) (Brusina 1902, Neubauer et al. 2013a).

\section{Melanopsis cvijici Brusina, 1902}

Figure 4E-N

* 1902 [Melanopsis] Cvijići Brus.; Brusina, pl. 29, figs 19-22.

1902 [Melanopsis] Bittneri Brus.; Brusina, pl. 7, figs 18-21 [non Melanopsis Bittneri Fuchs, 1877].

1929a Melanopsis cvijići Brusina. - Wenz, p. 2698.

1929a Melanoptychia bittneri Neumayr. - Wenz, p. 2869 [partim; only regarding Melanopsis Bittneri Brusina, 1902].

1974 Melanopsis cvijici Brusina. - Milan et al., p. 89.

2013a Melanopsis cvijici Brusina, 1902. - Neubauer et al., p. 134 , figs $4 \mathrm{i}-1$.

Material. - 15 specimens from NHMW 2014/0364/0001, NHMW 2014/0364/0009, NHMW 2014/0364/0017, NHMW 2014/0364/0018, NHMW 2014/0364/0019.

Type material. - The syntype (NHMZ 2900-546/1) from Fatelj, Kupres Basin, illustrated by Brusina (1902, pl. 29, figs 19, 20), was designated as lectotype by Milan et al. (1974); the other syntype of Brusina (1902, pl. 29, figs 21, 22) is apparently lost (Milan et al. 1974).

Dimensions. - Height: $17.21 \mathrm{~mm}$, width: $7.76 \mathrm{~mm}$ (Fig. 4E, F; lectotype from Fatelj; Brusina 1902, pl. 29, figs 21, 22); height: $17.87 \mathrm{~mm}$, width: $7.16 \mathrm{~mm}$ (Fig. 4G, H; probably syntype of Melanopsis Bittneri Brusina, 1902, pl. 7, figs 19, 20).

Figure 3. Melanopsidae. • A-C - Melanopsis angulata Neumayr, 1880. Neotype, NHMW 2014/0364/0012, from Džepi. • D, I - Melanopsis angulata Neumayr, 1880. NHMW 2014/0364/0014, from Džepi. • E, F - Melanopsis angulata Neumayr, 1880. NHMW 2014/0364/0015, from Džepi 1. - G, H - Melanopsis vitezovici Brusina, 1902. NHMW 2014/0364/0016, from Džepi 1. • J, K - Melanopsis mojsisovicsi (Neumayr, 1880). Neotype, 


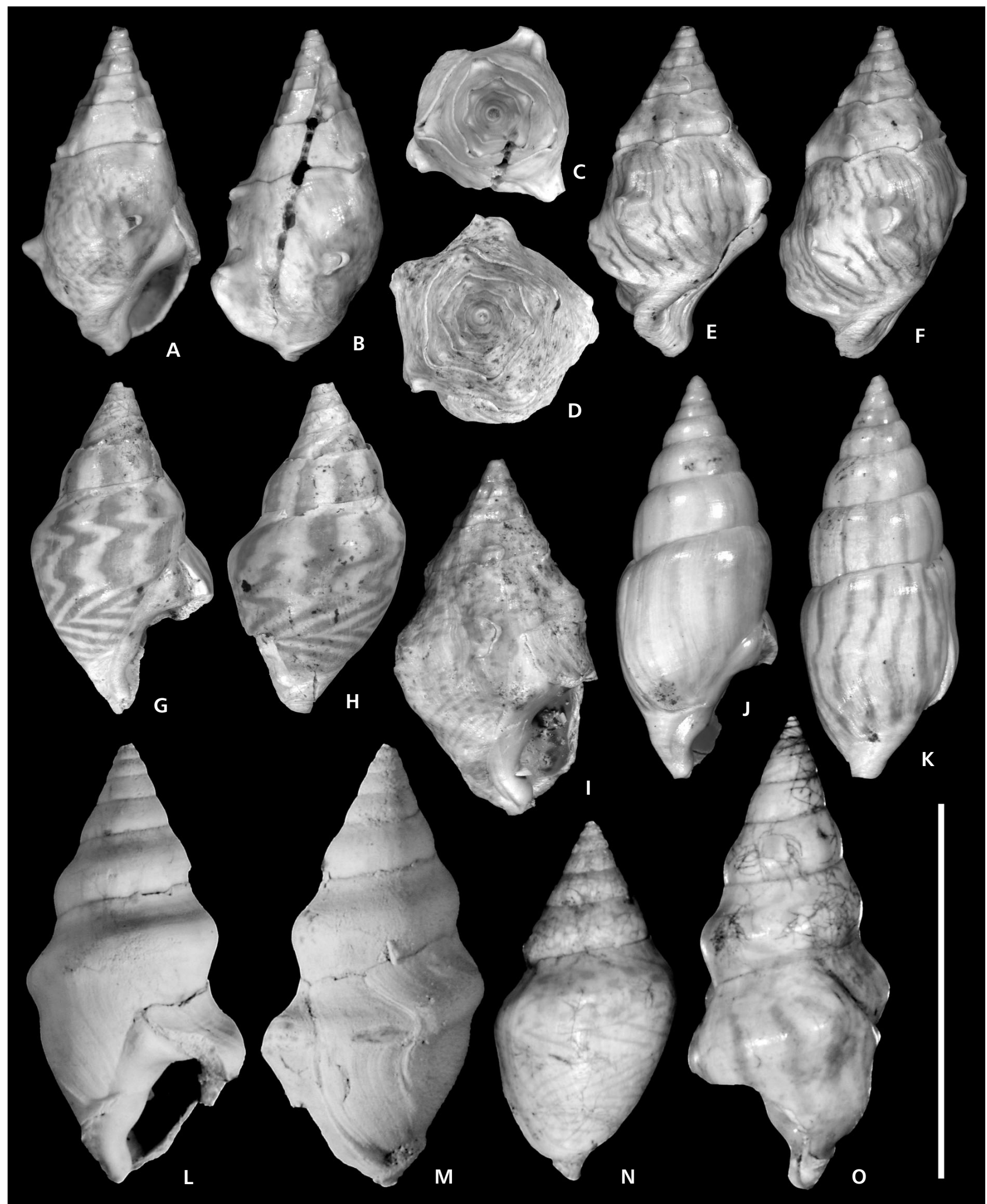

NHMW 2014/0364/0013, from Džepi. • L, M - Melanopsis vitezovici Brusina, 1902. Lectotype, illustrated in Brusina (1902, pl. 5, fig. 62), NHMZ 2501-147/1-4, from Džepi. $・$ N - Melanopsis vitezovici Brusina, 1902. Paralectotype 2, illustrated in Brusina (1902, pl. 5, fig. 63), NHMZ 2501-147/1-4, from Džepi. • O - Melanopsis vitezovici Brusina, 1902. Paralectotype 1, illustrated in Brusina (1902, pl. 5, fig. 61), NHMZ 2501-147/1-4, from Džepi. Scale bar corresponds to $10 \mathrm{~mm}$. 
Diagnosis. - Large-sized slender melanopsid with prominent axial ribs that are strongest in apical part and fade out towards base, producing stepped morphology; aperture narrow, without columellar fold but distinct fasciole.

Description. - Large-sized slender species, attaining up to $30 \mathrm{~mm}$ in height and $12 \mathrm{~mm}$ in width; comprises up to nine whorls. Early teleoconch whorls smooth, weakly convex; soon marked, broad, slightly oblique axial ribs emerge that are most prominent near upper suture, producing distinctly stepped morphology. Depending on time of rib initiation, shell outlines ranges from narrow, elliptical to rather ovoid. Expression of ribs varies between narrow, elongated and bulky, knob-like. Ribs become weaker towards base. Last whorl making up 50-70\% of total shell height. Aperture narrow, with slightly thickened callus pad, broad inner lip and distinct, sharp fasciole; no columellar fold is developed. In some specimens, coloring preserved as densely spaced, faint, brown zigzag lines (Fig. 4I, N), small brown dots (Fig. 4J, K), or intermediate patterns (Fig. 4L, M).

Discussion. - Brusina (1902) introduced Melanopsis cvijici for a species from the Fatelj in the Kupres Basin and Melanopsis bittneri from Džepi. The illustrated specimens may indeed argue for a taxonomic separation, given the sculptural differences that produce varied shell shapes. However, the present material revealed considerable morphological variability, including a series of intermediate stages (Fig. 4I-N). Therefore, we rather treat both species as single, highly polymorphic species and consider Melanopsis bittneri as junior synonym of $M$. cvijici. The morphological variability may also diverge between the two basins. A differentiation on subspecies level is still unsupported, as both morphological extremes co-occur in Džepi.

As already clarified by Neubauer et al. (2013a), Melanopsis bittneri Brusina, 1902 is a primary homonym of M. bittneri Fuchs, 1877. This problem was overlooked by Wenz (1929a), who erroneously treated Melanopsis bittneri sensu Brusina (1902) as a new combination of Melanoptychia bittneri Neumayr, 1880 (= Melanopsis medinae Neubauer, Mandic, Harzhauser \& Hrvatović, 2013; see above). Since we consider M. bittneri synonymous with $M$. cvijici, the introduction of a replacement name is not required.

The specimen from the collection of the NHMZ illustrated herein on Fig. 4G, $\mathrm{H}$ might be the syntype of
Melanopsis bittneri Brusina, 1902 [non Fuchs, 1877] from Džepi (illustrated on pl. 7, figs 19, 20). Unfortunately, that species was not treated by Milan et al. (1974) and no collection labels exist anymore. The illustrated specimen is remarkably similar to the drawings in Brusina (1902), corresponding in terms of shape, sculpture, the missing apex and the course of the fraction on the outer lip. Only the upper part of the aperture is lost in our specimen, while it is indicated on the drawing. Although we tentatively suggest the specimen to be the syntype (the additional fracture might have occurred later), this issue remains unsolved at present.

Occurrence. - Kupres Basin (Fatelj) and Prozor Basin (Džepi) (Brusina 1902, Neubauer et al. 2013a).

\section{Melanopsis mojsisovicsi (Neumayr, 1880)}

Figure 3J, K

* 1880 Melanoptychia Mojsisovicsi n.f.; Neumayr, p. 481, pl. 7, figs 9, 10 .

1880 Melanoptychia Bittneri Neum. - Bittner, p. 418.

1887 Melanoptychia Mojsisovicsi Neum. - Bittner, p. 299.

1929a Melanoptychia mojsisovicsi Neumayr. - Wenz, p. 2870.

non 2013a Melanopsis mojsisovicsi (Neumayr, 1880) comb. nov. - Neubauer et al., p. 137, figs 5e, f, i-k [= Melanopsis fateljensis Neubauer, Mandic \& Harzhauser, 2014].

Material. - 50 specimens from NHMW 2014/0364/0011, NHMW 2014/0364/0013; 1 from GBA 2009/026/0021.

Type material. - The type material, including all specimens studied by Neumayr (1880), is lost. Despite considerable effort to locate the material, the syntypes could not be found. Therefore, we define a neotype from material of the type locality to clarify the species' taxonomic status. There is no doubt that the neotype is conspecific with M. mojsisovicsi, since it fully corresponds to the illustrations provided by Neumayr (1880).

Neotype. - NHMW 2014/0364/0013 (Fig. 3J, K); height: $10.8 \mathrm{~mm}$, width: $4.4 \mathrm{~mm}$.

Figure 4. Melanopsidae. • A, B - Melanopsis carusi (Brusina, 1902). Neotype, GBA 2014/010/0002, from Džepi. • C, D - Melanopsis carusi (Brusina, 1902). Coll. NHMZ (no number), from Džepi. • E, F - Melanopsis cvijici Brusina, 1902. Lectotype from Fatelj, Kupres Basin, illustrated in Brusina (1902, pl. 29, figs 19, 20). • G, H - Melanopsis cvijici Brusina, 1902. Probably syntype of Melanopsis Bittneri Brusina, 1902 (pl. 7, figs 19, 20 ). Coll. NHMZ (no number), from Džepi. • I, N - Melanopsis cvijici Brusina, 1902. NHMW 2014/0364/0017, from Džepi 1. • J, K - Melanopsis cvijici Brusina, 1902. NHMW 2014/0364/0018, from Džepi. • L, M - Melanopsis cvijici Brusina, 1902. NHMW 2014/0364/0019, from Džepi 1. Scale bars correspond to $5 \mathrm{~mm}$. 


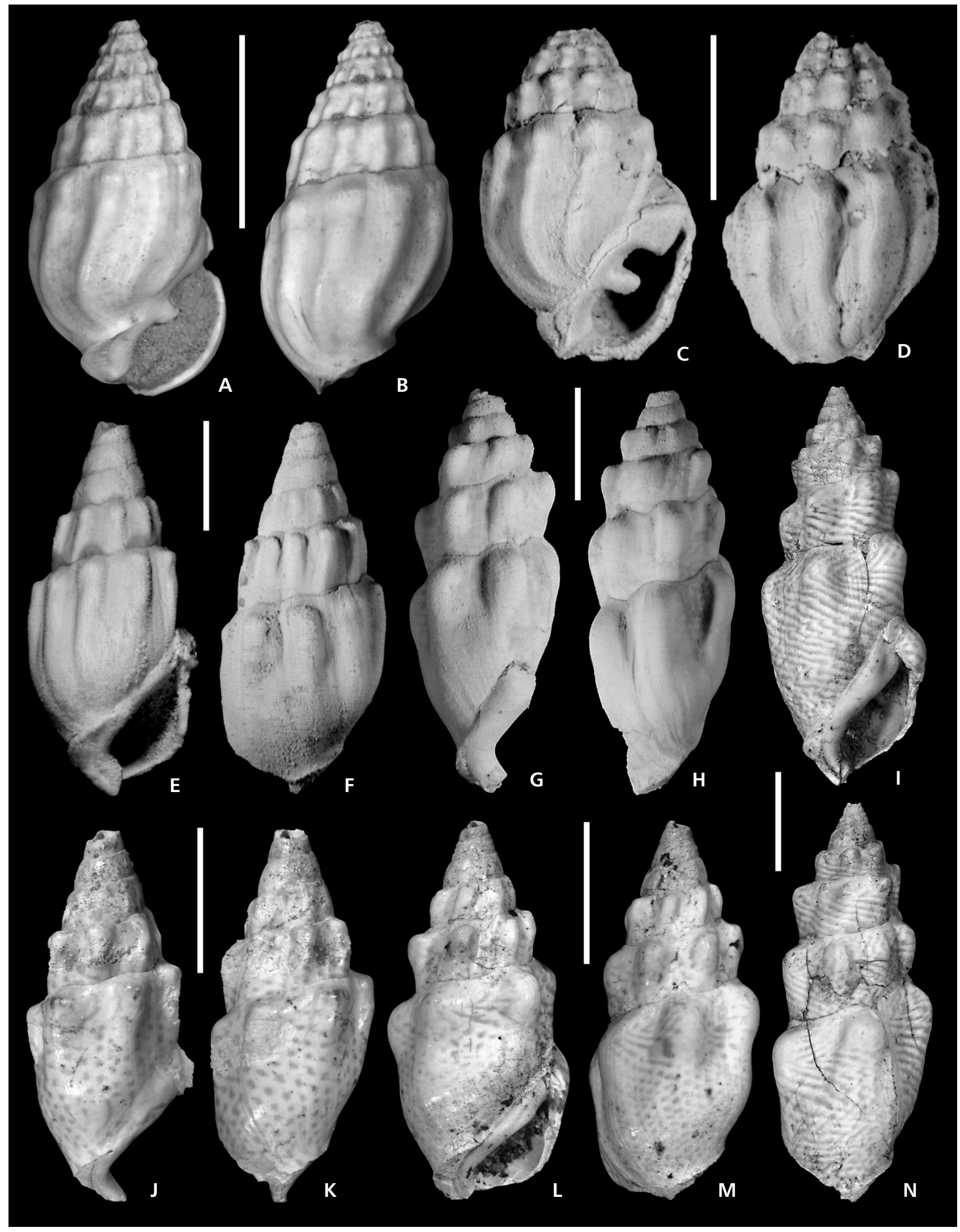


Type locality. - Džepi, Federation of Bosnia and Herzegovina, Bosnia and Herzegovina.

Type stratum. - Early middle Miocene (Langhian; Badenian) coal and limestone beds of the Prozor Basin.

Diagnosis. - Slender conical, unsculptured melanopsid with weakly convex to slightly stepped whorls, cylindrical last whorl, which attains $60-65 \%$ of total height, concave base and narrow aperture.

Description. - Slender conical shell, consisting of up to eight weakly convex to slightly stepped whorls. Early teleoconch starts conical, passes into approximately to sometimes perfectly cylindrical last whorl, which attains $60-65 \%$ of total height. Base concave, bearing thin fasciole. Aperture narrow, with thickened callus, glossy inner lip and very thin, sharp columellar fold. Coloring often preserved as axial, moderately spaced, thin, dark yellow, wavy lines.

Discussion. - The typical feature of this species is the cylindrical last whorl and the thin, sharp columellar fold, which allow a distinction from all other melanopsids. It slightly resembles $M$. visianiana Brusina, 1874 from about coeval deposits at Miočić in the Drniš Basin in terms of general shape and size as well as the concave base, but that species differs in its well-rounded last whorl (see also Neubauer et al. 2016). Melanopsis lanzaeana Brusina, 1874 from the Sinj Basin exhibits sometimes a similarly cylindrical but higher last whorl. The record of M. mojsisovicsi from the Kupres Basin by Neubauer et al. (2013a) was recently revised by Neubauer et al. (2014b), who introduced the new species $M$. fateljensis for the Kupres specimens. M. mojsisovicsi differs from M. fateljensis in its much higher last whorl and the lacking subsutural bulges typical for M. fateljensis. Moreover, the columellar fold typical for M. mojsisovicsi is absent in M. fateljensis.

Occurrence. - Endemic to the Prozor Basin (Džepi) (Neumayr 1880, Wenz 1929a).

\section{Melanopsis vitezovici Brusina, 1902}

Figure 3G, H, L-O

* 1902 [Melanopsis] Vitezovići [Brus.]; Brusina, pl. 5, figs 61-64.

1929a Melanopsis vitezovići Brusina. - Wenz, p. 2853.

1974 Melanopsis vitezovici Brusina. - Milan et al., p. 99.

Material. - Type material; 71 specimens from NHMW 2014/0364/0001, NHMW 2014/0364/0006, NHMW 2014/0364/0016; 1 from GBA 2008/155/0006.
Type material. - NHMZ 2501-147/1-4 (four syntypes); Džepi, Prozor Basin. We herewith designate the specimen illustrated on Fig. 3L-M as lectotype; the remaining three syntypes are paralectotypes.

Lectotype. - NHMZ 2501-147/1-4 (Fig. 3L, M; Brusina 1902, pl. 5, fig. 62); height: $11.74 \mathrm{~mm}$, width: $5.74 \mathrm{~mm}$.

Paralectotypes. - Paralectotype 1 (Fig. 3O; Brusina 1902, pl. 5, fig. 61; NHMZ 2501-147/1-4): height: $12.59 \mathrm{~mm}$, width: $5.32 \mathrm{~mm}$. Paralectotype 2 (Fig. 3N; Brusina 1902, pl. 5, fig. 63; NHMZ 2501-147/1-4): height: $9.62 \mathrm{~mm}$, width: $4.56 \mathrm{~mm}$. Paralectotype 3 (Brusina 1902, pl. 5, fig. 64; NHMZ 2501-147/1-4): height: $7.69 \mathrm{~mm}$, width: $3.78 \mathrm{~mm}$.

Type locality. - Džepi, Federation of Bosnia and Herzegovina, Bosnia and Herzegovina.

Type stratum. - Early middle Miocene (Langhian; Badenian) coal and limestone beds of the Prozor Basin.

Diagnosis. - Slender conical to deltoid melanopsid, bearing weak to prominent spiral bulge on last 2-3 whorls; aperture narrow, with thickened callus and weak columellar swelling.

Description. - Slender conical to deltoid shell, consisting of up to nine whorls. Early whorls weakly convex. On last 2-3 whorls marked spiral bulge emerges approximately at mid-height of whorl, ranging from weak, indistinct and broad to strong and rather thin. Last whorl attaining $60-70 \%$ of total shell height. Base straight to weakly convex, producing typical deltoid outline. Aperture narrow, exposing strongly thickened callus and weak columellar swelling. Coloring often preserved, exposed as axial, widely-spaced, broad, yellow, wavy bands or densely spaced, thin, yellow, zigzag lines; latter may disintegrate into round yellow spots where crossing spiral bulge.

Discussion. - Because of its typically formed bulge, this species can hardly be confused with any other melanopsid. The most similar species is $M$. sinjana Brusina, 1874, characterized by a high degree of morphological plasticity. It usually exhibits a similar bulge below the suture that often bears nodules or signs of round swellings; also, it has a more slender shape. Melanopsis bicoronata Brusina, 1884 has a similar morphology, but develops marked nodules on the bulge. $M e$ lanopsis camptogramma Brusina, 1876 corresponds in shape and the presence of a weak columellar swelling, but lacks the bulge. Melanopsis enodata Brusina, 1897 sometimes exhibits a comparable bulge, but has a smaller last whorl and often signs of axial swellings. All those species were described from about coeval deposits of the Sinj Basin. 
Occurrence. - Endemic to the Prozor Basin (Džepi) (Neumayr 1880, Wenz 1929a).

Family Pachychilidae Troschel, 1857

\section{Genus Tinnyea Hantken, 1887}

Type species. - Tinnyea vasarhelyii Hantken, 1887. Late Miocene; Pannonian Basin. Type by monotypy.

\section{Tinnyea sp.}

1887 Melania ex aff. Escheri Mer. - Bittner, p. 299.

1929a Brotia escheri auingeri (Handmann). - Wenz, p. 2590 [partim; only the record from Džepi].

Material. - None.

Discussion. - Bittner (1887) reported a "Melania" species from Džepi, yet with uncertain species identification. Wenz (1929a) synonymized this record with Brotia escheri auingeri (Handmann, 1882), although he seemingly had doubts about that grouping because he noted in the end that some of the records might refer to different subspecies (Wenz 1929a, p. 2592). The synonymization by Wenz (1929a) is, however, most probably incorrect, since Brotia escheri auingeri is a much younger taxon, described from upper Miocene deposits of Lake Pannon. It is very likely that the present taxon actually belongs to Tinnyea pilari (Neumayr, 1880) or Tinnyea verbasensis (Neumayr, 1883), which were originally described from the about coeval DLS localities Dugoselo (Croatia) and Banja Luka (Bosnia and Herzegovina), respectively (Fig. 1). Currently this issue remains unsolved as we lack material from Džepi; we list this species for the sake of completeness.

After the latest systematic revision, all species of "Brotia" and "Melanatria" and most "Melania" listed from the European Miocene-Pliocene are referred to the genus Tinnyea Hantken, 1887. For systematic update and nomenclatural comments on Brotia, Tinnyea and the "Melania escheri"-species complex see Kadolsky (1995) and Kowalke (2004).

Order Littorinimorpha Golikov \& Starobogatov, 1975

Superfamily Truncatelloidea Gray, 1840

Family Hydrobiidae Stimpson, 1865

Subfamily Belgrandiinae De Stefani, 1877

\section{Genus Cyclothyrella Neubauer, Mandic, Harzhauser \& Hrvatović, 2013}

Type species. - Litorinella candidula Neumayr, 1869. Middle Miocene; Dalmatia. Type by original designation.
Cyclothyrella tryoniopsis (Brusina, 1874)

Figure 5A, B

* 1874 Prososthenia tryoniopsis Brusina; Brusina, p. 50, pl. 3, figs 5,6 .

1902 [Prososthenia]? humilis [Brus.]; Brusina, pl. 8, figs 24-26.

1926 Prososthenia humilis Brusina. - Wenz, p. 1993.

1926 Prososthenia tryonopsis [sic] Brusina. - Wenz, p. 2003 [cum syn.].

1974 Prososthenia humilis Brusina. - Milan et al., p. 128.

1974 Prososthenia tryoniopsis Brusina. - Milan et al., p. 130.

? 1988 Prososthenia tryniopsis [sic] Brusina. - Jurišić-Polšak \& Slišković, p. 171.

2013a Cyclothyrella tryoniopsis (Brusina, 1874) comb. nov. - Neubauer et al., p. 138, figs 6b, g, j.

2016 Cyclothyrella tryoniopsis (Brusina, 1874). - Neubauer et al., p. 32, figs $5 \mathrm{~g}-\mathrm{k}$.

Material. - Type material of $P$. humilis only (3 syntypes), which is considered a junior synonym of $C$. tryoniopsis.

Type material. - Milan et al. (1974) erroneously referred to the "holotype" of C. tryoniopsis (NHMZ 3218-864), which was the only specimen illustrated in Brusina (1874). However, Brusina had a total of 15 specimens from Miočić in the Drniš Basin, all of them being syntypes. The statement of Milan et al. (1974) does not suffice as a valid lectotype designation (Art. 74.5). In order to settle this issue, we herewith designate the same specimen as lectotype.

Lectotype. - NHMZ 3218-864 (Brusina 1874, pl. 3, figs 5, 6; Neubauer et al. 2016, figs 5G, H); height: $3.80 \mathrm{~mm}$, width: $1.66 \mathrm{~mm}$.

Type locality. - Miočić, Šibenik-Knin County, Croatia.

Type stratum. - Early middle Miocene (Langhian; Badenian) lacustrine deposits of the Drniš Basin.

Additional measurements. - Height: $2.57 \mathrm{~mm}$, width: 0.93 mm (Fig. 5A, B; syntype of "Prososthenia" humilis; NHMZ 2569-215/1-3; Džepi, Prozor Basin; Brusina 1902, pl. 8, figs 24-26).

Discussion. - A detailed examination of this species, its synonyms and its systematic position is already provided by Neubauer et al. (2013a, 2016).

Occurrence. - Drniš Basin (Miočić, Parčić), Prozor Basin (Džepi), Kupres Basin (Fatelj), Sinj Basin (Trnovača) (Brusina 1874, 1902; Neubauer et al. 2013a). Its presence in the upper Miocene white marl of Tomislavgrad Basin 
(Šuica gaz) indicated by Jurišić-Polšak \& Slišković (1988) needs verification (see also Kochansky-Devidé \& Slišković 1981 and De Leeuw et al. 2011 for updated stratigraphy of that area).

\section{? Subfamily Pyrgulinae Brusina, 1881}

\section{Genus Illyricella gen. nov.}

Type species. - Illyricella dzepiensis sp. nov. Middle Miocene; Bosnia and Herzegovina.

Etymology. - After the ancient Roman province Illyricum encompassing the territory of the taxon's geographic distribution.

Affiliated species. - Type species only.

Diagnosis. - Tiny, slender, ovoid shell; protoconch exposing reticulate sculpture; last whorl large; aperture exposing the weak columellar fold; teleoconch covered with faint spiral grooves.

Discussion. - At a first glance, the smooth and ovoid shell of Illyricella dzepiensis gen. nov. sp. nov. appears quite ordinary, like found among many a hydrobiid species. However, the combination of a reticulate protoconch, a weak columellar swelling and a faint spiral sculpture is unique, which is why the introduction of a new genus is necessary.

Regarding its general morphology and thickened posterior tip, the new genus reminds of species of Prososthenia, e.g., P. neutra Brusina, 1897 or P. eburnea Brusina, 1897. However, Prososthenia clearly differs in its granulated protoconch. The species differs from representatives of the genus Cyclothyrella, which has a rounded, subcircular and detached aperture and a very slender shape. In particular, Cyclothyrella candidula (Neumayr, 1869) from the Sinj and Drniš basins is much more slender and exposes a stronger columellar fold (Neubauer et al. 2016); it only matches in terms of the reticulate protoconch. Species of the genus Odontohydrobia Pavlović, 1927 show a columellar swelling as well. This genus comprises a great variety of shell shapes, including extremely slender and elongated to broadly conical morphologies (Pavlović 1927), as well as stout and ton-shaped to irregular morphologies with an inflated penultimate whorl (Harzhauser et al. 2012). All of them share the open umbilicus, which is not developed in Illyricella.

Species of the genus Nematurella Sandberger, 1871 exhibit a terminal varix behind the peristome, which is missing in the present species. Also, the protoconch of Nematurella is apparently smooth or covered by a pattern of grooves and ridges (Kowalke \& Reichenbacher 2005). It also resembles Tournouerina belnensis (Delafond \&
Depéret, 1893) from the early Pleistocene of Bligny-surOuche in the Bresse Graben, concerning the thickened posterior tip and the slender ovoid shape. That species can be distinguished by the more oblique aperture and the stronger convex whorls. Tournouerina turiecensis Neubauer \& Harzhauser in Neubauer et al. (2015b) from the late Miocene of the Turiec Basin is larger, has a larger, more bulbous last whorl and the umbilicus is usually visible. Moreover, the protoconch of that species is weakly granulated instead of reticulate. The middle Miocene species Romania fastigata Neubauer \& Harzhauser in Harzhauser et al., 2012 from the Aflenz Basin in Austria has a typically straight-sided aperture that lacks the posterior indentation.

The genus is tentatively classified within the Pyrgulinae based on the ovoid shape of the shell and the drop-like, thickened aperture. Both characteristics are typical among Pyrgulinae (e.g., Prososthenia).

Occurrence. - So far only documented from the Prozor Ba$\sin (\mathrm{Džepi})$.

\section{Illyricella dzepiensis sp. nov.} Figure $5 \mathrm{C}-\mathrm{N}$

Etymology. - After the type locality.

Holotype. - NHMW 2014/0364/0036 (Fig. 5C-E, M, N); height: $2.3 \mathrm{~mm}$, width: $1.1 \mathrm{~mm}$.

Paratypes. - NHMW 2014/0364/0037 (Fig. 5F, G, K); height: $2.2 \mathrm{~mm}$, width: $1.0 \mathrm{~mm}$; NHMW 2014/0364/0038 (Fig. 5I, J); height: $2.3 \mathrm{~mm}$, width: $1.2 \mathrm{~mm}$.

Additional material. - Over 20 shells and fragments from sample Džepi 1 (NHMW 2014/0364/0001, NHMW 2014/0364/0039, NHMW 2014/0364/0040).

Type locality. - Džepi, Federation of Bosnia and Herzegovina, Bosnia and Herzegovina.

Type stratum. - Early middle Miocene (Langhian; Badenian) coal-limestone beds of the Prozor Basin.

Diagnosis. - Slender ovoid shell with reticulate protoconch; aperture drop-shaped, with weak columellar swelling and thickened posterior tip; faint spiral threads covering shell.

Description. - Shell slender ovoid, comprising up to five moderately convex whorls. Shell shape varies between slender (Fig. 5C-G) and stouter forms (Fig. 5H-J). Protoconch consisting of about one whorl, densely covered with marked reticulate pattern; transition to teleoconch indistinct. 


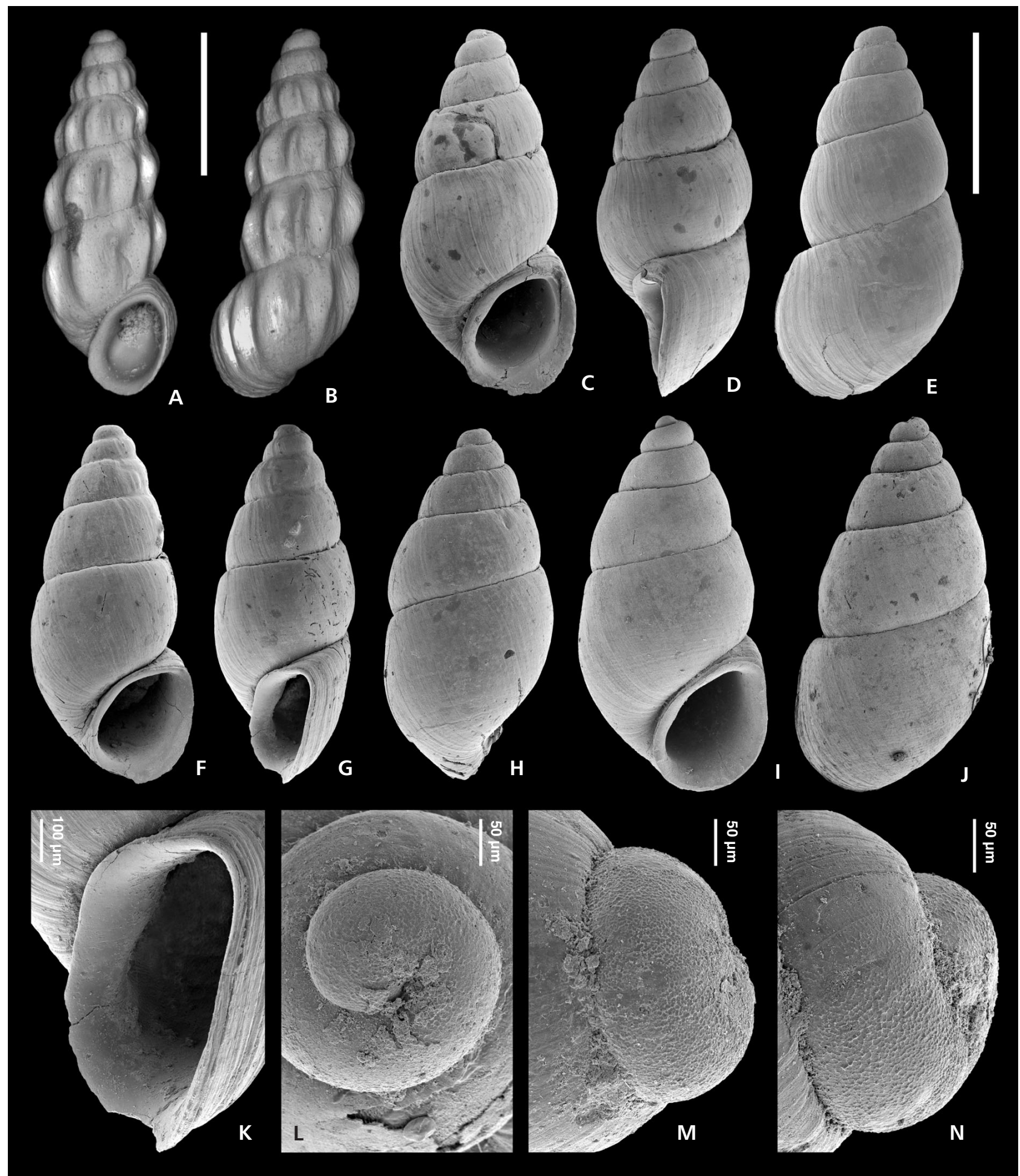

Figure 5. Hydrobiidae. - A, B - Cyclothyrella tryoniopsis (Brusina, 1874). Syntype of "Prososthenia" humilis, illustrated in Brusina (1902, pl. 8, figs 24-26), NHMZ 2569-215/1-3. • C-E, M, N - Illyricella dzepiensis sp. nov. Holotype, NHMW 2014/0364/0036, from Džepi 1. • F, G, K - Illyricella dzepiensis sp. nov. Paratype 1, NHMW 2014/0364/0037, from Džepi 1. • H - Illyricella dzepiensis sp. nov. NHMW 2014/0364/0039, from Džepi 1. - I, J - Illyricella dzepiensis sp. nov. Paratype 2, NHMW 2014/0364/0038, from Džepi 1. • L - Illyricella dzepiensis sp. nov. NHMW 2014/0364/0040, from Džepi 1. Scale bars correspond to $1 \mathrm{~mm}$ unless noted otherwise. 
Sutures strongly incised. Last whorl attaining $60-65 \%$ of total height, passing into straight base. Aperture widely drop-shaped, with expanded outer lip, slightly thickened inner, curved lip and markedly thickened posterior tip (because of successive displacement into abapical direction during late ontogeny). In lateral view, posterior part of inner lip protruding, while corresponding part of outer lip is shallowly indented. Weak columellar swelling developed (Fig. 5C, G, K). No umbilicus developed. Entire shell surface covered with distinct prosocline growth lines as well as numerous faint spiral grooves, which are most distinct on the base of the last whorl (Fig. 5H, I).

Discussion. - A very similar species is Stenothyrella? ovoidea (Pavlović, 1927) from the Pannonian of Belgrade, Serbia (Pavlović 1927) and Soceni, Romania (Jekelius 1944). It has a similar size and shape and even corresponds in the presence of spiral furrows, yet differs in the usually not covered umbilicus and the lacking columellar swelling. For more comparisons see discussion of the genus.

Occurrence. - Endemic to the Prozor Basin (Džepi).

\section{Genus Marticia Brusina, 1897}

Type species. - Hydrobia tietzei Neumayr, 1880. Middle Miocene; Bosnia and Herzegovina. Type by original designation (Brusina 1897: footnote on p. XV).

\section{Marticia tietzei (Neumayr, 1880)}

Figure 6A-C, K

* 1880 Hydrobia Tietzei n. f.; Neumayr, p. 482, pl. 7, fig. 13. 1880 Hydrobia Tietzei Neum. - Bittner, p. 418.

1881 Pyrgula? Tietzei Neumayr. - Brusina, p. 265.

1887 Hydrobia Tietzei Neum. - Bittner, p. 299.

1897 Martićia Tietzei (Neum.). - Brusina, p. XV. 1902 Martićia Tietzei (Neum.). - Brusina, pl. 7, figs 39-41. 1926 Marticia tietzei (Neumayr). - Wenz, p. 2125.

Material. - 27 specimens from NHMW 2014/0364/0001, NHMW 2014/0364/0005; 22 from GBA 2008/008/0115, GBA 2008/010/0041, GBA 2008/010/0042, GBA 2014/ 010/0003, GBA 2014/010/0005, GBA 2014/010/0006.

Type material. - The type material, with all specimens studied by Neumayr (1880), is lost. Despite considerable effort to locate the material, the syntypes could not be found. In order to clarify the species' taxonomic status, we define a neotype from material of the type locality. The neotype is undoubtedly conspecific with $M$. tietzei, as it clearly matches the illustrations given by Neumayr (1880).
Neotype. - GBA 2014/010/0003 (Fig. 6A, B); height: $9.1 \mathrm{~mm}$, width: $3.8 \mathrm{~mm}$.

Type locality. - Džepi, Federation of Bosnia and Herzegovina, Bosnia and Herzegovina.

Type stratum. - Early middle Miocene (Langhian; Badenian) coal-limestone beds of the Prozor Basin.

Additional measurements. - Largest specimen attains $c a$ $11 \mathrm{~mm}$ in height and $4.5 \mathrm{~mm}$ in width.

Diagnosis. - Slender ovoid hydrobiid with marked, broad spiral swelling close to upper suture, additional, weaker swelling close to lower suture, and delicate, densely spaced spiral grooves on straight-sided whorl portions between swellings.

Description. - Slender ovoid shell, comprising up to nine whorls. Protoconch not sufficiently preserved; apparently smooth. Early teleoconch smooth. Soon broad spiral swelling occurs below suture, which passes into distinct bulge on last whorl; no ramp is developed. On last few whorls another, weaker swelling may form above lower suture. Whorl portion between swellings straight-sided, covered with numerous, delicate, densely spaced spiral grooves. Sutures weakly incised. Last whorl attains almost half of total shell height; grades into straight to slightly concave base. Aperture elliptical, sharply terminated. Although it is weakly detached from the base, it covers the umbilicus almost completely. Prosocline growth lines cover shell.

Discussion. - As correctly indicated by Brusina (1897), this species has nothing in common with Hydrobia and can be also well delimited from Pyrgula, Prososthenia and other hydrobiid genera. Marticia hidalgoi Brusina, 1902 from the Kupres Basin differs in its stouter, conical shape with stepped whorls. Marticia cosensis (Magrograssi, 1928) from the early Pleistocene of Kos Island has a similar outline but a very bulbous upper keel. Pyrgula brusinai Tournouër, 1875, co-occurring with the latter species, was considered a Marticia by Willmann (1981), but lately affiliated with Pseudodianella by Neubauer et al. (2013a). It can be distinguished by its drop-shaped to conical morphology and the presence of three spiral bulges.

A very similar species is Marticia pauli (Fuchs, 1877) from the late Miocene of Kálamos, East Attica, Greece. It resembles the present species in terms of outline and sculptural pattern, but differs in the markedly weaker expression of the lower angulation, which never forms a strong bulge as in M. tietzei. For whatever reason, Willmann (1981) rejected the classification of $M$. pauli within Marticia and placed it tentatively within Goniochilus. That genus was introduced by Sandberger (1872) for elongated hydrobiids bearing axial ribs from the 


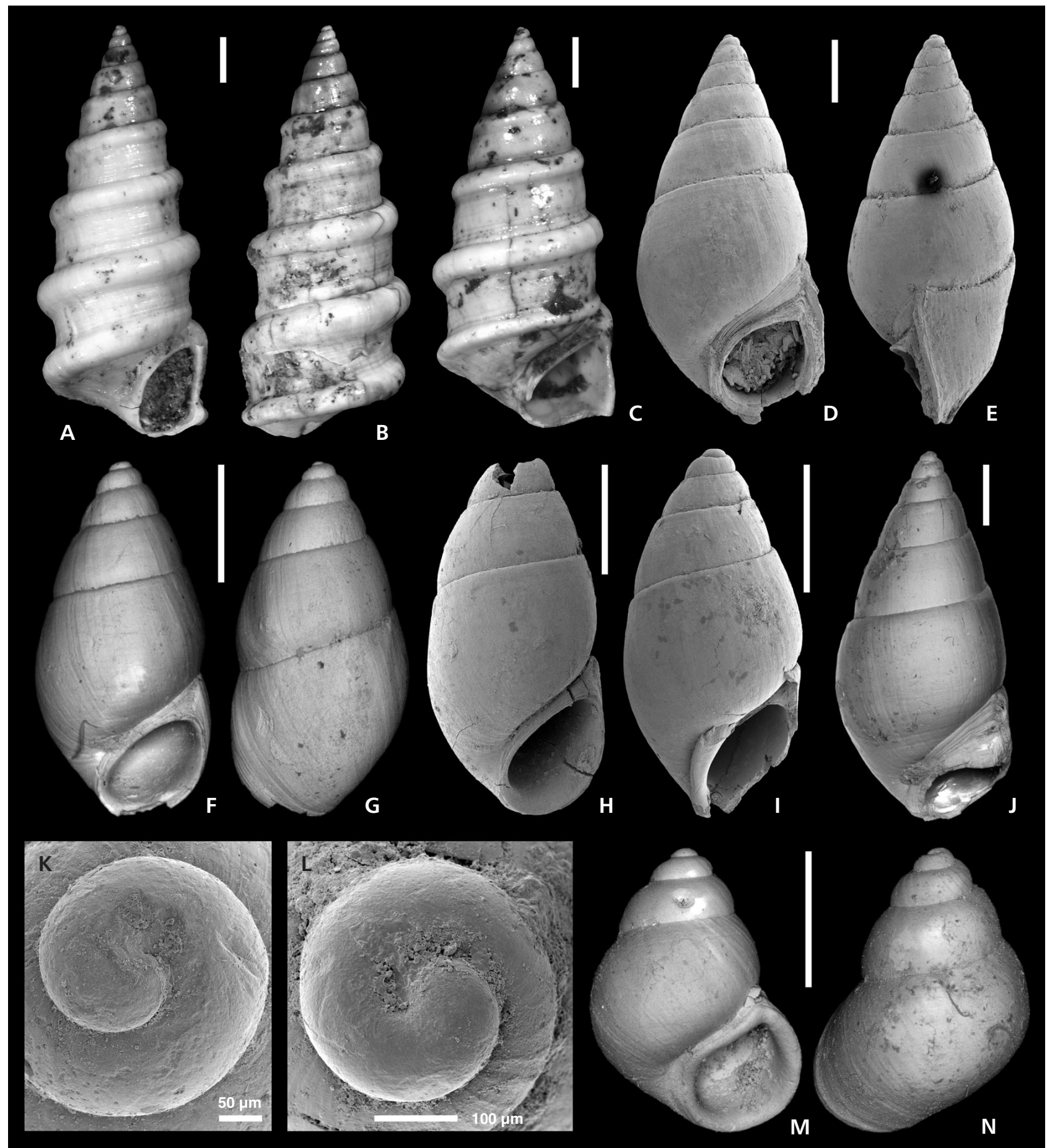

Figure 6. Hydrobiidae. A A, B - Marticia tietzei (Neumayr, 1880). Neotype, GBA 2014/010/0003, from Džepi. •C - Marticia tietzei (Neumayr, 1880). GBA 2014/010/0005, from Džepi. •D, E, L - Prososthenia? stenostoma (Brusina, 1902). NHMW 2014/0364/0020, from Džepi 1. • F, G - Prososthenia? bosnensis (Brusina, 1902). Lectotype, illustrated in Brusina (1902, pl. 8, fig. 72), NHMZ 2584-232/1-3, from Džepi. • H - Prososthenia? bosnensis (Brusina, 1902). NHMW 2014/0364/0021, from Džepi 1. • I - Prososthenia? bosnensis (Brusina, 1902). NHMW 2014/0364/0022, from Džepi 1. - J - Prososthenia? stenostoma (Brusina, 1902). Lectotype, illustrated in Brusina (1902, pl. 8, fig. 69), NHMZ 2585-231/1-3, from Džepi. $•$ - Marticia tietzei (Neumayr, 1880). GBA 2014/010/0006, from Džepi. • M, N - Bania? pachychila (Brusina, 1902). Lectotype, illustrated in Brusina (1902, pl. 9 , fig. 39), NHMZ 2599-245/1-4. Scale bars correspond to $1 \mathrm{~mm}$ unless noted otherwise. 
late Miocene of Rădmănești (Lake Pannon). Apart from the elongated shape, $M$. pauli has little in common with Goniochilus. The morphological similarity to the present species justifies the classification within Marticia as proposed by Wenz (1926). A more detailed examination of the protoconch sculpture of the Greek species would be necessary to clarify potential relationships.

Occurrence. - Endemic to the Prozor Basin (Džepi) (Neumayr 1880, Wenz 1926).

\section{Genus Prososthenia Neumayr, 1869}

Type species. - Prososthenia schwartzi Neumayr, 1869. Middle Miocene; Dalmatia. Type by subsequent designation (Clessin 1880).

\section{Prososthenia? bosnensis (Brusina, 1902) comb. nov.} Figure 6F-I

* 1902 [Stenothyra?] bosnensis [Brus.]; Brusina, pl. 8, figs 72-74.

1926 Stenothyra bosnensis Brusina. - Wenz, p. 2210.

1974 Stenothyra bosnensis Brusina. - Milan et al., p. 136.

Material. - Type material; 2 specimens from NHMW 2014/0364/0021, NHMW 2014/0364/0022.

Type material. - NHMZ 2584-232/1-3 (three syntypes); Džepi, Prozor Basin. We herewith designate the specimen illustrated on Fig. 6F-G as lectotype; the remaining syntypes are paralectotypes.

Lectotype. - NHMZ 2584-232/1-3 (Fig. 6F, G; Brusina 1902, pl. 8, fig. 72); height: $3.13 \mathrm{~mm}$, width: $1.54 \mathrm{~mm}$.

Type locality. - Džepi, Federation of Bosnia and Herzegovina, Bosnia and Herzegovina.

Type stratum. - Early middle Miocene (Langhian; Badenian) coal and limestone beds of the Prozor Basin.

Additional measurements. - Height: $2.9 \mathrm{~mm}$, width: $1.4 \mathrm{~mm}$ (Fig. 6I).

Diagnosis. - Small, deltoid shell with up to five whorls, tightly coiled whorls, narrow aperture and extraordinarily thickened inner lip and posterior tip.

Description. - Small, deltoid shell with up to five whorls. Protoconch unknown. Whorls low convex, separated by moderately incised sutures. Last whorl bluntly angulated around mid-height, producing typical deltoid shell shape; passes into straight base. Last whorl attains two thirds of shell height. Aperture small, oblique. In late ontogeny growth direction of peristome changes: growth in coiling direction decreases, while growth in abapical direction increases; this produces narrowed aperture and massively thickened inner lip and posterior tip. Latter remains tightly attached to previous whorl. Umbilicus covered. Prosocline growth lines cover whole shell.

Discussion. - This species, as well as the following one, was initially classified within the genus Stenothyra Benson, 1856. The family Stenothyridae, which is presently confined to East and Southeast Asia, was represented by at least three genera (Stenothyrella Wenz, 1939, Stenothyroides Lozouet, 1985, Stenothyropsis Kadolsky, 1988) and several species during the Cenozoic in Europe (Lozouet 1985). Species attributed to these genera are characterized by broad, often elliptical and sometimes irregularly coiled shells. Because of increasing translation during ontogeny, the last whorl is more slender and the aperture becomes centralized (Hershler \& Ponder 1998). This often gives the impression of a thickened posterior tip. Typical Stenothyra also expose numerous, small, densely spaced, spirally arranged pits on the shell surface. The present species, however, shows none of these features; its shape classifies it as belonging to the Hydrobiidae. Given the similarities with several species of Prososthenia, regarding shape and apertural thickening (see, e.g., Neubauer et al. 2011, 2013a), we tentatively affiliate both "Stenothyra" bosnensis as well as "Stenothyra" stenostoma (see below) with that genus. Prososthenia? bosnensis differs from Prososthenia? stenostoma mainly in its smaller size; latter species attains about the double height and has two more whorls. Moreover, P.? bosnensis has more convex whorls, a higher last whorl and a less thickened aperture.

Occurrence. - Endemic to the Prozor Basin (Džepi) (Brusina 1902, Wenz 1926).

Prososthenia? stenostoma (Brusina, 1902) comb. nov. Figure 6D, E, J, L

* 1902 [Stenothyra?] stenostoma [Brus.]; Brusina, pl. 8, figs 69-71.

1926 Stenothyra stenostoma Brusina. - Wenz, p. 2229.

1974 Stenothyra stenostoma Brusina. - Milan et al., p. 137.

Material. - Type material; 2 specimens from NHMW 2014/0364/0001, NHMW 2014/0364/0020.

Type material. - NHMZ 2585-231/1-3 (three syntypes); Džepi, Prozor Basin. We herewith designate the specimen illustrated on Fig. 6J as lectotype; the remaining syntypes are paralectotypes. 
Lectotype. - NHMZ 2585-231/1-3 (Fig. 6J; Brusina 1902, pl. 8, fig. 69); height: $6.22 \mathrm{~mm}$, width: $2.96 \mathrm{~mm}$.

Type locality. - Džepi, Federation of Bosnia and Herzegovina, Bosnia and Herzegovina.

Type stratum. - Early middle Miocene (Langhian; Badenian) coal and limestone beds of the Prozor Basin.

Additional measurements. - Height: $6.2 \mathrm{~mm}$, width: $3.0 \mathrm{~mm}$ (Fig. 6D, E, L).

Diagnosis. - Deltoid shell with up to seven whorls, tightly coiled whorls, narrow aperture and extraordinarily thickened inner lip and posterior tip.

Description. - Slender, deltoid shell with up to seven whorls. Protoconch granulated, consisting of $\mathrm{ca} 0.9$ whorls; transition to teleoconch marked by onset of prosocline growth lines. Whorls low convex, almost straight-sided, separated by moderately incised sutures. Whorls covered by numerous spiral grooves, which are most distinct on last whorl. Last whorl bluntly angulated around mid-height, producing typical deltoid shell shape; passes into straight base. Last whorl attains two thirds of shell height. Aperture small, oblique. In late ontogeny growth direction of peristome changes: growth in coiling direction decreases, while growth in abapical direction increases; this produces narrowed aperture and massively thickened inner lip and posterior tip. Latter remains tightly attached to previous whorl. Umbilicus covered.

Discussion. - For details about the revised systematic classification and differences to co-occurring Prososthenia? bosnensis see discussion of that species.

Occurrence. - Endemic to the Prozor Basin (Džepi) (Brusina 1902, Wenz 1926).

Subfamily unassigned

\section{Genus Bania Brusina, 1896}

Type species. - Stalioa prototypica Brusina, 1872. Middle Miocene; Dalmatia. Type by monotypy (ICZN 2001).

\section{Bania? pachychila (Brusina, 1902)}

Figure 6M, N

* 1902 [Bythinella]? pachychila [Brus.]; Brusina, pl. 9, figs 36-39.

1926 Amnicola (Amnicola) pachychila (Brusina). - Wenz, p. 2072.
1974 Amnicola (Amnicola) pachychila Brusina. - Milan et al., p. 63.

Material. - Type material only.

Type material. - NHMZ 2599-245/1-4 (four syntypes); Džepi, Prozor Basin. We herewith designate the specimen illustrated on Fig. 6M, N as lectotype; the remaining syntypes are paralectotypes.

Lectotype. - NHMZ 2599-245/1-4 (Fig. 6M-N; Brusina 1902, pl. 9, fig. 39); height: $2.15 \mathrm{~mm}$, width: $1.64 \mathrm{~mm}$.

Type locality. - Džepi, Federation of Bosnia and Herzegovina, Bosnia and Herzegovina.

Type stratum. - Early middle Miocene (Langhian; Badenian) coal and limestone beds of the Prozor Basin.

Diagnosis. - Small, stout hydrobiid with four convex, tightly coiled whorls, drop-shaped aperture with marked posterior notch, and markedly thickened peristome leaving no umbilicus.

Description. - Stout, ovoid shell with up to four convex whorls, separated by weakly incised sutures. Protoconch unknown. Last whorl attaining $75 \%$ of shell height. Base straight. Aperture drop-shaped, not detached, with posterior notch and all around equally thickened peristome. Umbilicus covered. Shell smooth apart from prosocline growth lines.

Discussion. - No additional specimens could be detected in the material available to us, so we cannot estimate the full morphological range of this species. The generic classification tentatively follows Neubauer et al. (2013a), who affiliated the present species with Bania based on overall shell similarities. Unfortunately, the protoconch, which would show a strong reticulate sculpture in the case of a real Bania, is unknown. Bania? pachychila can be distinguished from $B$. stosiciana (Brusina, 1874) and B. torbariana (Brusina, 1874) from the Sinj and Drniš basins based on their stronger convex to stepped whorls and rarely thickened apertures. Bania? dokici (Brusina, 1902) from Dugoselo (Glina Basin) has a non-thickened aperture and a little slenderer shape.

Occurrence. - Endemic to the Prozor Basin (Džepi) (Brusina 1902, Wenz 1926).

Clade Panpulmonata Jörger et al., 2010

Order Hygrophila Férussac, 1822 
Superfamily Planorboidea Rafinesque, 1815

Family Planorbidae Rafinesque, 1815

\section{Genus Orygoceras Brusina, 1882}

Type species. - Orygoceras cornucopiae Brusina, 1882 (currently considered as a synonym of Orygoceras dentaliforme Brusina, 1882). Middle Miocene; Dalmatia. Type by subsequent designation by Cossmann (1921).

\section{Orygoceras dentaliforme Brusina, 1882}

Figure 7C-I

* 1882 Orygoceras dentaliforme nov. spec.; Brusina, p. 42, pl. 11, figs 9-15.

1882 Orygoceras stenonemus nov. spec.; Brusina, p. 43, pl. 11, figs 4-8.

1882 Orygoceras cornucopiae nov. spec.; Brusina, p. 45, pl. 11, figs $1-3$.

1887 Orygoceras dentaliforme Brus. - Bittner, p. 299.

1887 Orygoceras stenonemus Brus. - Bittner, p. 299.

1902 [Orygoceras] curvum [Brus.]; Brusina, pl. 2, figs 2-5.

1902 [Orygoceras] bifrons [Brus.]; Brusina, pl. 2, figs $6-14$.

2016 Orygoceras dentaliforme Brusina, 1882. - Neubauer et al., p. 45, figs 8n-o, r [cum syn.].

Material. - Type material of $O$. bifrons (9 syntypes; NHMZ 2389-35 to 2397-43) and $O$. curvum (4 syntypes; NHMZ 2385-31 to 2389-34), which are considered junior synonyms of $O$. dentaliforme; 3 fragments from NHMW 2014/0364/0001; 3 fragments from GBA 2008/006/0035.

Type material. - NHMZ 3574-1214/1a, NHMZ 3576-1216/1a (2 syntypes of $O$. dentaliforme); both from Ribarić, Sinj Basin.

Dimensions. - Height: $6.90 \mathrm{~mm}$, width: $1.25 \mathrm{~mm}$ (syntype; Brusina 1882, pl. 11, figs 13, 14); height: $4.72 \mathrm{~mm}$, width: $0.72 \mathrm{~mm}$ (syntype; Brusina 1882, pl. 11, figs 11, 12); height: $4.00 \mathrm{~mm}$, width: $0.93 \mathrm{~mm}$ (Fig. 7D; syntype of $O$. bifrons; NHMZ 2389-35 to 2397-43; Brusina 1902, pl. 2, fig. 8); height: $1.96 \mathrm{~mm}$, width: $0.44 \mathrm{~mm}$ (Fig. 7C; syntype of O. bifrons; NHMZ 2389-35 to 2397-43; Brusina 1902, pl. 2, fig. 10); height: $2.91 \mathrm{~mm}$, width: $0.83 \mathrm{~mm}$ (Fig. 7E, F; syntype of $O$. curvum; NHMZ 2385-31 to 2389-34; Brusina 1902, pl. 2, fig. 4); height: $3.17 \mathrm{~mm}$, width: $0.56 \mathrm{~mm}$ (Fig. 7H-I; syntype of O. curvum; NHMZ 2385-31 to 2389-34; Brusina 1902, pl. 2, fig. 2); height: $2.95 \mathrm{~mm}$, width: $0.50 \mathrm{~mm}$ (Fig. 7G; syntype of 0 . curvum; NHMZ 2385-31 to 2389-34; Brusina 1902, pl. 2, fig. 3).

Discussion. - Brusina (1902) illustrated but never provided any description or discussion for $O$. bifrons and $O$. curvum.
The characteristics on which he based the delimitation of $O$. bifrons from similar species like O. cornucopiae or O. stenonemus from the Sinj and Drniš basins, which fully correspond in terms of shape and sculpture, are not known. Likewise, O. curvum matches $O$. dentaliforme regarding shape and the lack of sculpture. Following Neubauer et al. (2011, 2013a, b, 2016), all these species are considered synonymous and may reflect local variations; the presence and expression of sculpture seems to be highly variable in that genus. For more detailed descriptions and discussions on this widespread species see there.

Occurrence. - Drniš Basin (Miočić, Parčić), Gacko Basin (Gračanica, Vrbica), Glina Basin (Dugoselo), Prozor Basin (Džepi), Udbina Basin (Laudonov Gaj), Kupres Basin (Fatelj), Sinj Basin (Lučane, Ribarić, Strmendolac-Crveni klanac, Trnovača, Župića potok) (Brusina 1882, 1884, 1897, 1902; Bittner 1887; Jurišić-Polšak et al. 1993, 2000; Neubauer et al. 2013a, b). Its presence in the late Miocene of the Tomislavgrad Basin (Šuica gaz) and Livno Basin (Čelebić-Jaruga) indicated by Jurišić-Polšak \& Slišković (1988) needs verification.

\section{Orygoceras tropidophorum Brusina, 1902} Figure 7A, B

* 1902 Orygoceras tropidophorum Brus.; Brusina, pl. 2, fig. 1.

1928 Orygoceras tropidophorum Brusina. - Wenz, p. 2491.

1974 Orygoceras tropidophorum Brusina. - Milan et al., p. 116.

Material. - Type material only.

Type material. - NHMZ 2384-30 (syntype); Džepi, Prozor Basin. It is unknown whether this is the only specimen Brusina had at hand when describing the species (holotype by monotypy) or whether there are additional syntypes.

Dimensions. - Height: 2.35 mm, width: 0.73 mm (Fig. 7A, B; syntype; Brusina 1902, pl. 2, fig. 1).

Diagnosis. - Uncoiled, dentaliform, curved shell with two distinct, offset, lateral keels.

Description. - Shell uncoiled, dentaliform, curved. Protoconch consisting of about 0.5 still coiled whorls. Teleoconch curved, bearing two distinct, offset, lateral keels, leading from protoconch to aperture. Surface additionally covered with numerous fine striae, parallel to keels. Shell slightly flattened on one side, so that keels lie below median shell diameter. Aperture near semilunar. 


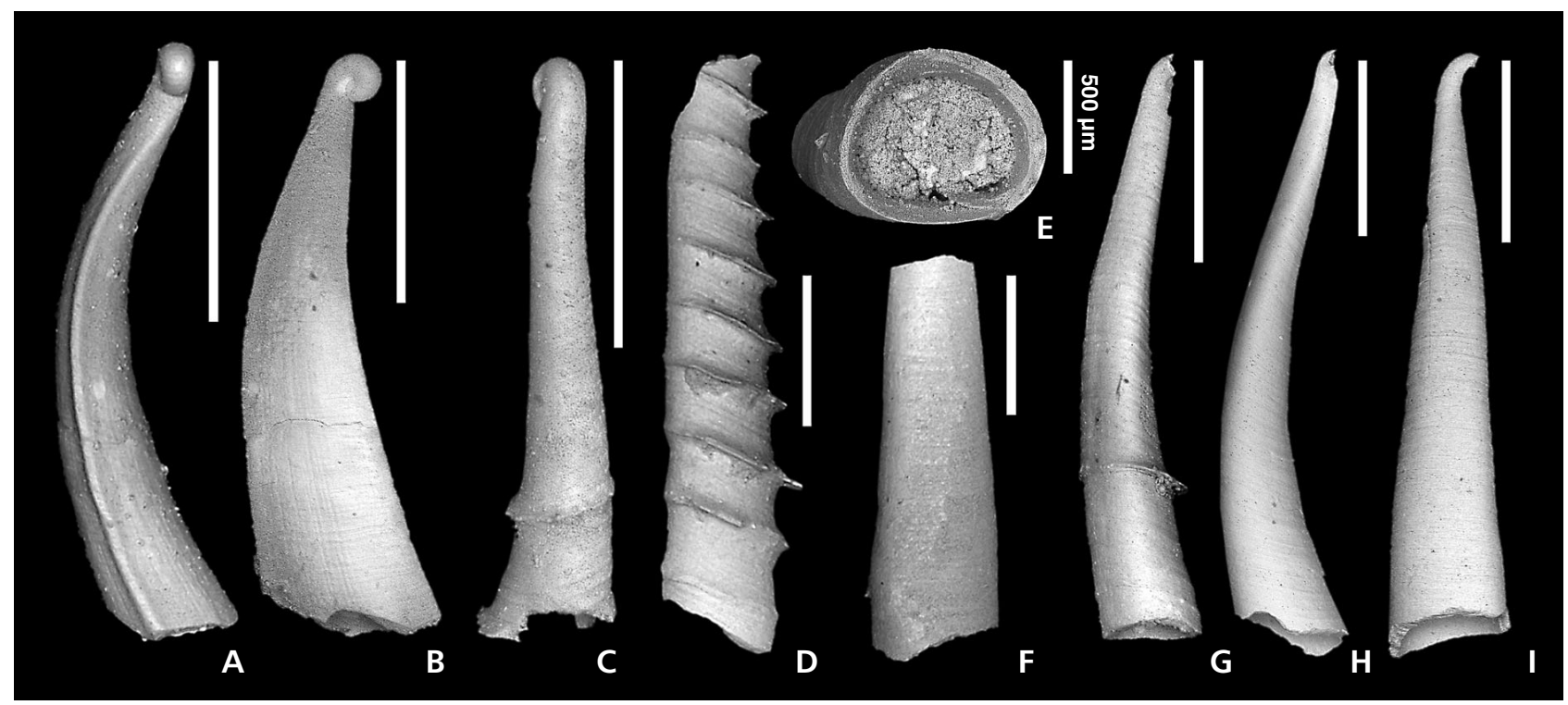

Figure 7. Planorbidae. A A, B - Orygoceras tropidophorum Brusina, 1902. Syntype, illustrated in Brusina (1902, pl. 2, fig. 1), NHMZ $2384-30$. - C - Orygoceras dentaliforme Brusina, 1882. Syntype of O. bifrons, illustrated in Brusina (1902, pl. 2, fig. 10), NHMZ 2389-35 to 2397-43. - D - Orygoceras dentaliforme Brusina, 1882. Syntype of $O$. bifrons, illustrated in Brusina (1902, pl. 2, fig. 8), NHMZ 2389-35 to 2397-43. - E, F - Orygoceras dentaliforme Brusina, 1882. Syntype of O. curvum, illustrated in Brusina (1902, pl. 2, fig. 4), NHMZ 2385-31 to 2389-34. - G - Orygoceras dentaliforme Brusina, 1882. Syntype of O. curvum, illustrated in Brusina (1902, pl. 2, fig. 3), NHMZ 2385-31 to 2389-34. - H, I - Orygoceras dentaliforme Brusina, 1882. Syntype of O. curvum, illustrated in Brusina (1902, pl. 2, fig. 2), NHMZ 2385-31 to 2389-34. All specimens from Džepi. Scale bars correspond to $1 \mathrm{~mm}$ unless noted otherwise.

Discussion. - This species can be well distinguished from the co-occurring $O$. dentaliforme. The lateral keels are never found in that species or any other known Orygoceras. It has not been detected in the newly collected material; the only available material is the single type specimen.

Occurrence. - Endemic to the Prozor Basin (Džepi) (Brusina 1902, Wenz 1928).

\section{Discussion}

\section{Faunal composition and paleoecology}

The lacustrine gastropod fauna from Džepi is composed of 15 species (Table 1). No quantitative analysis was feasible as most of the material originated from old surface collections, but the most common species appeared to be $M$. tiet$z e i, M$. mojsisovicsi and $M$. vitezovici, which is largely congruent with the observations by Katzer (1921). Ten gastropod species are endemic to the locality Džepi $(66.6 \%)$ and all species are restricted to the DLS. Given the high endemism, the relationship to other coeval DLS lakes is rather low. The fauna has each two species in common with those of the lakes Sinj, Kupres and Drniš (Neubauer et al. 2011, 2013a, 2016), accounting for $14.3 \%$ of the similarity (only species-level identifications are considered). Only a single species, Orygoceras dentaliforme, is shared with Lake Gacko (7.1\%; Neubauer et al. 2013b). Regarding the degree of endemism, the Džepi fauna by far outcompetes these other lakes (Sinj: $38.6 \%$, Kupres: $30.4 \%$, Drniš: 9.1\%, Gacko: 0\%; Neubauer et al. 2015a) and makes it unique among DLS lakes. In terms of genus and family composition as well as the morphological spectrum, the Džepi fauna is most similar to that of Lake Kupres. Both systems are characterized by a similar number of gastropod species (17 for Kupres, 15 for Džepi) and the presence of several species of Melanopsis, the hydrobiid genera Cyclothyrella, Marticia, Prososthenia and Bania, one species of Theodoxus and the planorbid genus Orygoceras. This analogy may at least partly reflect similar ecological conditions in both lakes. The generic composition with abundant melanopsids and hydrobiids but rare pulmonates is typical among DLS faunas and characteristic of shallow long-lived lakes (Jurišić-Polšak et al. 1993; Harzhauser \& Mandic 2008; Bulić \& Jurišić-Polšak 2009; Neubauer et al. 2011, 2013a, b, 2016; Krstić et al. 2013). Regarding the morphological diversity, both faunas expose a considerable number of highly sculptured and/or thickened shells, even among rarely sculptured genera like Theodoxus. Neubauer et al. (2013a) related these developments in the species from the Kupres Basin to carbonate oversaturation and alkaline lake waters favoring excessive shell accretion. This model may also apply to the fauna of Džepi, where carbonate was unlikely a limiting factor considering the underlying and surrounding Triassic limestone (Fig. 1). 
Table 1. List of freshwater gastropod species occurring in Džepi.

\begin{tabular}{|c|c|c|c|c|c|c|}
\hline Species & Džepi as type locality & Endemic to Džepi & Lake Kupres & Lake Sinj & Lake Drniš & Lake Gacko \\
\hline Theodoxus reiseri (Brusina, 1902) & $\times$ & $\times$ & & & & \\
\hline Melanopsis angulata Neumayr, 1880 & $\times$ & $x$ & & & & \\
\hline Melanopsis carusi (Brusina, 1902) & $x$ & & $x$ & & & \\
\hline Melanopsis cvijici Brusina, 1902 & & & $x$ & & & \\
\hline Melanopsis mojsisovicsi (Neumayr, 1880) & $x$ & $\times$ & & & & \\
\hline Melanopsis vitezovici Brusina, 1902 & $x$ & $x$ & & & & \\
\hline \multicolumn{7}{|l|}{ Tinnyea sp. } \\
\hline Cyclothyrella tryoniopsis (Brusina, 1874) & & & & $x$ & $\times$ & \\
\hline Illyricella dzepiensis gen. nov. sp. nov. & $x$ & $x$ & & & & \\
\hline Marticia tietzei (Neumayr, 1880) & $x$ & $x$ & & & & \\
\hline Prososthenia? bosnensis (Brusina, 1902) & $\times$ & $x$ & & & & \\
\hline Prososthenia? stenostoma (Brusina, 1902) & $x$ & $x$ & & & & \\
\hline Bania? pachychila (Brusina, 1902) & $\times$ & $\times$ & & & & \\
\hline Orygoceras dentaliforme Brusina, 1882 & & & & $\times$ & $\times$ & $\times$ \\
\hline Orygoceras tropidophorum Brusina, 1902 & $\times$ & $\times$ & & & & \\
\hline
\end{tabular}

Additionally to the gastropods, the deposits contain fragments of the dreissenid bivalves Illyricocongeria cf. aletici (Brusina, 1907) and I. cf. moirae (Mandic in Neubauer et al., 2016), as well as unidentifiable remains of unionids and a crocodile tooth (Bittner 1887, Katzer 1921, material of the NHMW collection). Both dreissenid species have been recently documented in detail from the Drniš Basin (Neubauer et al. 2016; for discussions on generic attributions see there).

\section{Biostratigraphy}

Based on the similarity of the mollusk composition with that recorded for the Kupres Basin (15.5 $\pm 0.2 \mathrm{Ma}$; Neubauer et al. 2013a), the age of the deposits at Džepi was estimated as early Langhian by Neubauer et al. (2013b). The present material, specifically the occurrence of the dreissenids Illyricocongeria cf. aletici and I. cf. moirae, allows a more detailed assessment of the stratigraphic age. Both species are endemic to the DLS and occur coevally in a narrow timeframe. De Leeuw et al. (2010) recently established a biochronological frame for the aletici-lineage, constraining I. aletici to the interval between 15.3 and 15.0 Ma. This biostratigraphic marker species also occurs in the Kupres and Sinj basins, while I. moirae is endemic to Lake Drniš (15.7-15.0 Ma; Neubauer et al. 2016). Consequently, we propose an age of $c a$ 15.3-15.0 Ma (early Langhian; early Badenian) for the Džepi deposits.

Despite being geographically close, the Džepi fauna differs considerably from that recovered from other parts of the Prozor Basin. After Katzer (1921) and Wenz
(1923-1930) and material stored in the NHMW collection, the fauna documented from the localities Konjic-Repovica and Podbor-Šcit (Fig. 1) consists of a smooth Theodoxus, ribbed Melanopsis species, Tinnyea sp., Fossarulus cf. tricarinatus Brusina, 1870, Pseudodianella haueri (Neumayr, 1869) and small hydrobiids. Although most of the former identifications are tentative and to some extent doubtful and in need of revision, they demonstrate a different composition than that reported here from Džepi and might indicate a different age. So far, a middle Miocene age was indicated by the presence of large mammals in the locality Konjic-Repovica, i.e., the proboscideans Prodeinotherium bavaricum (von Meyer, 1831) and Gomphotherium angustidens (Cuvier, 1817) and the rhinoceratids Hoploaceratherium tetradactylum (Lartet, 1851), Brachypotherium brachypus (Lartet, 1837) and Dorcatherium cf. crassum (Lartet, 1851) (MN 6-MN 7+8; Malez \& Slišković 1964, 1965, 1976; Rössner \& Heissig 1999). The finding of the dreissenid bivalve Trigonipraxis cf. zoisi (Andrusov, 1897) (coll. Th. Fuchs, 1892, NHMW, det. O. Mandic) from that locality suggests a slightly older age. (The generic classification of $T$. zoisi follows Starobogatov, 1970; for a discussion and thorough systematic revision of regional dreissenid faunas see Neubauer $e t$ al. 2016.) This biostratigraphic marker species belongs to a slightly older evolutionary lineage than I. aletici and indicates a latest early to early middle Miocene age for Konjic-Repovica; its occurrence in the Glina Basin was dated with $16.0 \mathrm{Ma}$ (MN 5; Mandic et al. 2012). In combination with the occurrence of the gastropod $P$. haueri, which has been reported from the Sinj, Livno and Kupres basins (Wenz 1923-1930, Neubauer et al. 2013a) and the lowermost strata of the Drniš Basin (Neubauer et al. 2016), 


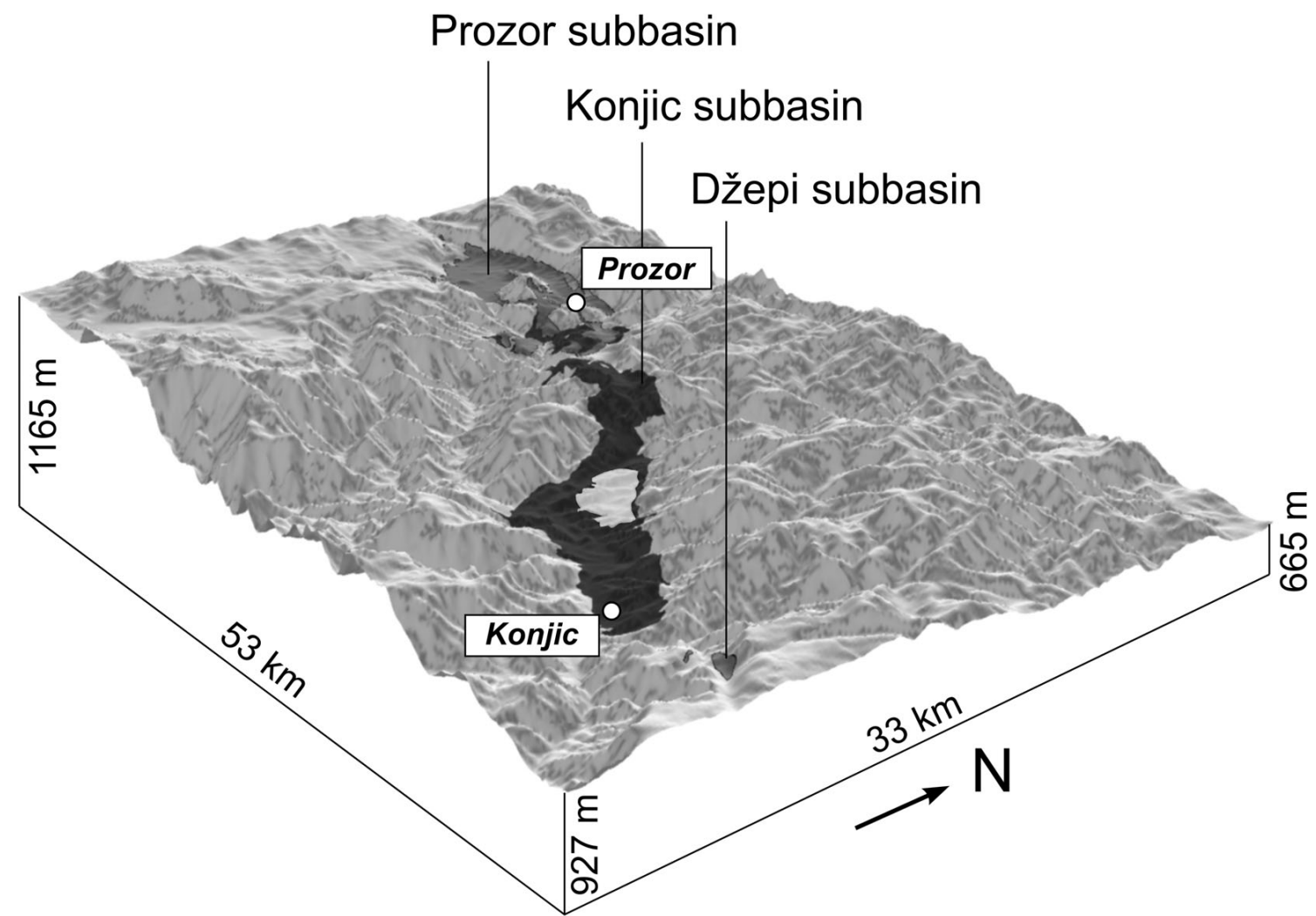

Upper unit (150-400 m) conglomerates, breccia, and sandstone

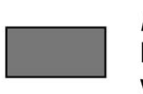

Middle unit (150-400 m) limestone, marl and clay with coal
Lower unit $(200 \mathrm{~m})$

breccia, conglomerates

and sandstone

Figure 8. Topographic model of the Prozor Basin created in ArcGIS 10.0, indicating geographic distribution of major lithological units based on geological maps (Mojićević \& Laušević 1971, Jovanović et al. 1977, Sofilj \& Živanović 1979, Mojićević \& Tomić 1982). The underlying digital elevation model with a resolution of 3 arc seconds is based on data collected by the 2000 Shuttle Radar Topography Mission and freely available from http://viewfinderpanoramas.org (ver. 5 August 2012).

we propose an age of $c a 16.0-15.5$ Ma for the mollusk-bearing deposits of the central and western part of the Prozor Basin (Fig. 8).

\section{Notes on regional paleogeography}

The paleogeographic affiliation of the freshwater Miocene at Džepi is still unclear. The limestone deposits at Džepi form an isolated occurrence much higher elevated ( $c a$ $800 \mathrm{~m}$ a.s.1.) than the carbonates of the Prozor Basin (Fig. 8). In addition, the peculiar gastropod fauna has not been identified from other parts of the basin. Because of this, Bittner (1880) and Katzer (1921) treated it as isolated environment and did not discuss a potential relationship to other systems. In contrast, Sofilj et al. (1980) considered the freshwater limestones of Džepi to belong to the middle sedimentary unit of the Prozor Basin (Fig. 8), based on lithological similarities. Today's geographic isolation may be owed to post-sedimentary tectonic displacement, while the absence of the Middle Unit in the Konjic subbasin is considered a result of erosion. The complex tectonic history of the region is unfortunately still largely unresolved (e.g., Tari 2002, Schmid et al. 2008, Korbar 2009). More data on regional tectonics and local, temporally well-constrained mollusk faunas from other parts of the basin need to be acquired in order to clarify the paleoenvironmental evolution of the Prozor Basin as a whole.

\section{Acknowledgments}

We are grateful to Zlata Jurišić-Polšak and Maria Bošnjak (both Croatian Natural History Museum in Zagreb, NHMZ) and Irene Zorn (Austrian Geological Survey, GBA) for providing access to the type collections. Nives Borčić made the photographs and Hrvoje Posilovic the SEM documentation of the type material stored at the NHMZ. Mladen Juračić and Zlatan Bajraktarević facilitated access to the SEM device at the Geological Department, Faculty of Science, University of Zagreb. We acknowledge permission by the NHMZ to publish this documentation. The field 
investigation highly profited from the support by Hazim Hrvatović (Geological Survey Sarajevo) and would have not been possible without his organizational help. Ursula Göhlich (NHMW) helped with literature on the large mammals. The reviews by Daniela Esu (University of Rome), Dietrich Kadolsky (Surrey, United Kingdom) and an anonymous reviewer are greatly appreciated. This work contributes to the projects "Freshwater systems in the Neogene and Quaternary of Europe: Gastropod biodiversity, provinciality, and faunal gradients" (Project No. P25365-B25) and "Mollusk evolution of the Miocene Dinaride Lake Systems" (Project No. P18519-B17) financed by the Austrian Science Fund FWF.

\section{References}

Adams, H. \& AdAms, A. 1853-1858. The genera of Recent Mollusca arranged according to their organizations. 2 vols of text (661 pp.), 1 vol. of plates. Van Voorst, London.

Andrusov, N. 1897. Fossile und lebende Dreissenidae Eurasiens. 683 pp. Tipografiya M. Merkusheva, St. Petersburg.

Benson, W.H. 1856. New land shells collected by E.A. Layard, Esq., and described by W.H. Benson, Esq. The Annals and Magazine of Natural History, Series 2 18, 433-439.

BitTner, A. 1880. Die Hercegowina und die südöstlichen Theile von Bosnien. Jahrbuch der Kaiserlich-königlichen geologischen Reichsanstalt 30(2), 353-438.

BitTner, A. 1887. Zur Kenntniss der Melanopsidenmergel von Džepe bei Konjica in der Hercegovina. Verhandlungen der Kaiserlich-königlichen geologischen Reichsanstalt 1887(16), 298-300.

Bouchet, P. \& Rocroi, J.-P.E. 2005. Classification and Nomenclator of Gastropod Families. Malacologia 47(1-2), 1-397.

Bourguignat, J.R. 1880. Étude sur les fossiles tertiaires et quaternaires de la vallée de la Cettina en Dalmatie. $55 \mathrm{pp}$. Imprimerie D. Bardin, Saint Germain.

Brusina, S. 1870. Monographie der Gattungen Emmericia und Fossarulus. Verhandlungen der kaiserlichen und königlichen zoologisch-botanischen Gesellschaft in Wien 20, 925-938.

BrusinA, S. 1872. Naravoslovne crtice sa sjevero-istočne obale Jadranskoga mora. Dio prvi. Putopis. Rad Jugoslavenske akademije znanosti i umjetnosti 19, 105-177.

Brusina, S. 1874. Fossile Binnen-Mollusken aus Dalmatien, Kroatien und Slavonien nebst einem Anhange. 138 pp. Actienbuchdruckerei, Agram.

BRUsinA, S. 1876. Decription d'espèces nouvelles, provenant des terrains tertiaires de Dalmatie. Journal de Conchyliologie 24, 109-116.

Brusina, S. 1878. Molluscorum fossilium species novae et emendatae in tellure tertiaria Dalmatiae, Croatiae et Slavoniae inventae. Journal de Conchyliologie 26, 347-356.

Brusina, S. 1881. Le Pyrgulinae dell'Europa orientale. Bollettino della Società Malacologica Italiana 7(13-19), 229-292.

BRusina, S. 1882. Orygoceras. Eine neue Gasteropodengattung der Melanopsiden-Mergel Dalmatiens. Beiträge zur Paläontologie Österreich-Ungarns und des Orients 2, 33-46.

Brusina, S. 1884. Die Neritodonta Dalmatiens und Slavoniens nebst allerlei malakologischen Bemerkungen. Jahrbücher der Deutschen Malakozoologischen Gesellschaft 11, 17-120.

BRusina, S. 1892. Fauna fossile terziaria di Markusevec in Croazia. Con un elenco delle Dreissensidae della Dalmazia, Croazia e Slavonia. Glasnik Hrvatskoga naravoslovnoga društva 7, 113-210.

BrusinA, S. 1896. Neogenska zbirka iz Ugarske, Hrvatske, Slavonije i Dalmacije na Budimpestanskoj izlozbi. Glasnik Hrvatskoga naravoslovnoga drustva 9, 98-150.

Brusina, S. 1897. Gragja za neogensku malakološku faunu Dalmacije, Hrvatske i Slavonije uz neke vrste iz Bosne i Hercegovine i Srbije. Djela Jugoslavenske akademije znanosti i umjetnosti 18,1-43.

BrusinA, S. 1902. Iconographia Molluscorum Fossilium in tellure tertiaria Hungariae, Croatiae, Slavoniae, Dalmatiae, Bosniae, Herzegovinae, Serbiae and Bulgariae inventorum. Officina Soc. Typographicae, Agram.

Brusina, S. 1907. Naravoslovne crtice sa sjevero-istočne obale Jadranskoga mora. Dio cetvrti i posljednji. Specijalni. Rad Jugoslavenske akademije znanosti i umjetnosti 169, 195-251.

Bulić, J. \& JuRIŠIĆ-PoLŠAK, Z. 2009. Macropalaeontology and Stratigraphy of Lacustrine Miocene Deposits at Crnika Beach on the Island of Pag (Croatia). Geologica Croatica 62(3), 135-156. DOI $10.4154 / \mathrm{gc} .2009 .16$

Clessin, S. 1880. Studien über die Familie der Paludinen. Malakozoologische Blätter (Neue Folge) 2, 161-196.

Cossmann, M. 1921. Essais de Paléoconchologie Comparée. Douzième Livraison. 348 pp. Privately published, Paris.

Cox, L.R. 1960. Thoughts on the classification of the Gastropoda. Proceedings of the Malacological Society of London 33, 239-261.

Criscione, F. \& Ponder, W.F. 2013. A phylogenetic analysis of rissooidean and cingulopsoidean families (Gastropoda: Caenogastropoda). Molecular Phylogenetics and Evolution 66, 1075-1082. DOI 10.1016/j.ympev.2012.11.026

Cuvier, G. 1795. Second Mémoire sur l'organisation et les rapports des animaux à sang blanc, dans lequel on traite de la structure des Mollusques et de leur division en ordre, lu à la société d'Histoire Naturelle de Paris, le 11 prairial an troisième. Magasin Encyclopédique, ou Journal des Sciences, des Lettres et des Arts 2, 433-449.

Cuvier, G. 1817. Le règne animal distribué d'après son organisation, pour servir de base à l'histoire naturelle des animaux et d'introduction à l'anatomie comparée. Tome 1. 540 pp. Deterville, Paris.

Delafond, F. \& DepéRet, C. 1893. Études des Gîtes minéraux de la France. Les terrains tertiaires de la Bresse et leurs gîtes de lignite et de minerais de fer. 332 pp. Imprimerie Nationale, Paris.

De Leeuw, A., Mandic, O., Krijgsman, W., Kuiper, K. \& HrvaTOVIĆ, H. 2011. A chronostratigraphy for the Dinaride Lake System deposits of the Livno-Tomislavgrad Basin: the rise and fall of a long-lived lacustrine environment. Stratigraphy 8(1), 29-43. 
De Leeuw, A., Mandic, O., Krijgsman, W., Kuiper, K. \& HrvaTOVIĆ, H. 2012. Paleomagnetic and geochronologic constraints on the geodynamic evolution of the Central Dinarides. Tectonophysics 530-531, 286-298.

DOI 10.1016/j.tecto.2012.01.004

De Leeuw, A., Mandic, O., Vranjković, A., Pavelić, D., Harzhauser, M., Krijgsman, W. \& Kuiper, K.F. 2010. Chronology and integrated stratigraphy of the Miocene Sinj Basin (Dinaride Lake System, Croatia). Palaeogeography, Palaeoclimatology, Palaeoecology 292(1-2), 155-167. DOI 10.1016/j.palaeo.2010.03.040

De Stefani, C. 1877. Molluschi continentali fino ad ora notati in ltalia nei terreni pliocenici, ed ordinamento di questi ultimi. Atti della Societa Toscana di Scienze Naturali Residente in Pisa 3(2), 274-325.

FÉrussac, A.E.J.P.J.F.D'A.D. 1821-1822. Tableaux systématiques des animaux mollusques classés en familles naturelles, dans lesquels on a établi la concordance de tous les systèmes; suivis d'un prodrome général pour tous les mollusques terrestres ou fluviatiles, vivants ou fossiles. $110 \mathrm{pp}$. Bertrand, Sowerby, Paris, Londres.

Férussac, J.B.L.D’A.D. \& FérussaC, A.E.J.P.J.F.D’A.D. 1807. Essai d'une méthode conchyliologique appliquée aux mollusques fluviatiles et terrestres d'après la considération de l'animal et de son test. Nouvelle édition augmentée d'une synonymie des espèces les plus remarquables, d'une table de concordance systématique de celles qui ont été décrites par Géoffroy, Poiret et Draparnaud, avec Müller et Linné, et terminée par un catalogue d'espčces observées en divers lieux de la France. xvi + 142 pp. Delance, Paris.

FLEMING, J. 1822. The philosophy of zoology, a general view of the structure, functions and classification of animals, 2. 618 pp. Constable \& Co., Edinburgh.

FRÝDA, J. 1998. Higher classification of the Paleozoic gastropods inferred from their early shell ontogeny, 108. In BIELER, R. \& Mikkelsen, P.M. (eds) $13^{\text {th }}$ International Malacological Congress, Abstracts. Washington D.C.

Fuchs, T. 1877. Studien über die jüngeren Tertiärbildungen Griechenlands. Denkschriften der mathematisch-naturwissenschaftlichen Klasse der Kaiserlichen Akademie der Wissenschaften 37(2), 1-42.

Golikov, A.N. \& Starobogatov, Y.I. 1975. Systematics of prosobranch gastropods. Malacologia 15(1), 185-232.

Gray, J.E. 1840. Shells of molluscous animals, 105-152. Synopsis of the contents of the British Museum, $42^{\text {th }}$ edition. G. Woodfall, London.

Gray, J.E. 1847. A list of the genera of recent Mollusca, their synonyma and types. Proceedings of the Zoological Society of London 15, 129-242.

Handmann, R. 1882. Die fossile Molluskenfauna von Kottingbrunn. Jahrbuch der Kaiserlich-königlichen geologischen Reichsanstalt 32, 543-564.

HantKen, M.v. 1887. Tinnyea Vásárhelyii nov. gen. et nov. spec. Földtani Közlöny 17(4), 345-348.

Harzhauser, M. \& MANDic, O. 2008. Neogene lake systems of Central and South-Eastern Europe: Faunal diversity, gradients and interrelations. Palaeogeography, Palaeoclimatology, Palaeoecology 260(3-4), 417-434.

DOI 10.1016/j.palaeo.2007.12.013

Harzhauser, M. \& Mandic, O. 2010. Neogene dreissenids in Central Europe: evolutionary shifts and diversity changes, 11-29. In VAn der Velde, G., Rajagopal, S. \& Bij de VaAte, A. (eds) The Zebra Mussel in Europe. Backhuys Publishers, Leiden/Margraf Publishers, Weikersheim.

Harzhauser, M., Neubauer, T.A., Mandic, O., Zuschin, M. \& Ćorić, S. 2012. A Middle Miocene endemic freshwater mollusc assemblage from an intramontane Alpine lake (Aflenz Basin, Eastern Alps, Austria). Paläontologische Zeitschrift 86(1), 23-41. DOI 10.1007/s12542-011-0117-x

Hershler, R. \& Ponder, W.F. 1998. A Review of Morphological Characters of Hydrobioid Snails. Smithsonian Contributions to Zoology 600, 1-55. DOI 10.5479/si.00810282.600

InTERnATIONAL COMmission On ZoOlogical NomenClature 1999. International Code of Zoological Nomenclature. 306 pp. International Trust for Zoological Nomenclature, London.

InTERnATIONAL COMMission ON ZoOlOgical Nomenclature 2001. Opinion 1965: Euchilus Sandberger, 1870 and Stalioa Brusina, 1870 (Mollusca: Gastropoda): Bithinia deschiensiana Deshayes, 1862 and Paludina desmarestii Prévost, 1821 designated as the respective type species, with the conservation of Bania Brusina, 1896. Bulletin of Zoological Nomenclature 58(1), 63-65.

Jekelius, E. 1944. Sarmat und Pont von Soceni (Banat). Memoriile Institutului geologic al României 5, 1-167.

Jörger, K.M., StöGer, I., Kano, Y., Fukuda, H., KnebelsberGER, T. \& SCHRÖDL, M. 2010. On the origin of Acochlidia and other enigmatic euthyneuran gastropods, with implications for the systematics of Heterobranchia. BMC Evolutionary Biology 10, 323. DOI 10.1186/1471-2148-10-323

Jovanović, R., MojIčević, M., Tокić, S. \& Rokić, L. 1977. Osnovna geološka karta SFRJ 1:100.000. List Sarajevo K341. Savezni geološki zavod, Beograd.

JURIŠIĆ-POLŠAK, Z. 1979. Miocenske i pliocenske neritide u Hrvatskoj. Palaeontologia Jugoslavica 22, 1-50.

JURIŠIĆ-POLŠAK, Z. 1984. Novi fosarulusi u slatkovodnom neogenu Dalmacije (južna Hrvatska). Rad Jugoslaveske akademije znanosti i umjetnosti 411, 197-208.

Jurišić-PolšAK, Z., Bulić, J. \& Posilović, H. 2000. Pojava visokospecijaliziranih oblika nekih gastropoda u miocenskim slatkovodnim naslagama Crvenog Klanca, Sinjsko polje, Hrvatska. Proceedings Second Croatian Geological Congress, Cavtat-Dubrovnik, 231-237. Zagreb.

Jurišić-Polšak, Z., KrizManić, K. \& HaJeK-TAdesse, V. 1993. Freshwater Miocene of Krbavsko Polje in Lika (Croatia). Geologica Croatica 46(2), 213-228.

JURIŠIĆ-POLŠAK, Z. \& SLIŠKOVIĆ, T. 1988. Slatkovodni gastropodi neogenskih naslaga jugozapadne Bosne. Zbornik referata naučnog skupa "Minerali, stijene, izumrli i živi svijet BIH", Zemaljski Muzej Bosne i Hercegovine, Sarajevo, 7.-8. oktobar 1988, 167-174.

KadOLSKY, D. 1988. Stratigraphie und Molluskenfaunen von "Landschneckenkalk" und "Cerithienschichten" im Mainzer 
Becken (Oberoligozän bis Untermiozän?). Stratigraphische, paläogeographische und paläoökologische Ergebnisse. Geologisches Jahrbuch A110, 69-133.

KadOLSKY, D. 1995. Stratigraphie und Molluskenfaunen von "Landschneckenkalk" und "Cerithienschichten" im Mainzer Becken (Oberoligozän bis Untermiozän?), 2: Revision der aquatischen Mollusken des Landschneckenkalkes. Archiv für Molluskenkunde 124(1/2), 1-55.

Katzer, F. 1921. Die fossilen Kohlen Bosniens und der Hercegovina. Zweiter Band. 271 pp. Verlag der Bosn.-Herc. Geologischen Landesanstalt, Sarajevo.

Kochansky-Devidé, V. \& SlišKović, T. 1978. Miocenske kongerije Hrvatske, Bosne i Hercegovine. Palaeontologia jugoslavica 19, 1-98.

Kochansky-Devidé, V. \& SLIŠKović, T. 1981. Mlade miocenske kongerije Livanjskog, Duvanjskog i Kupreškog polja u jugozapadnoj Bosni i Hodova u Hercegovini. Palaeontologia jugoslavica 25, 1-25.

Korbar, T. 2009. Orogenic evolution of the External Dinarides in the NE Adriatic region: a model constrained by tectonostratigraphy of Upper Cretaceous to Paleogene carbonates. Earth-Science Reviews 96, 296-312. DOI 10.1016/j.earscirev.2009.07.004

Kowalke, T. 2004. Evolution of the Pachychilidae Troschel, 1857 (Caenogastropoda, Cerithioidea) - from the Tethys to modern tropical rivers. Zitteliana A 44, 41-50.

Kowalke, T. \& Reichenbacher, B. 2005. Early Miocene (Ottnangian) Mollusca of the Western Paratethys ontogenetic strategies and palaeo-environments. Geobios 38, 609-635. DOI 10.1016/j.geobios.2004.03.006

Krstić, N., Jovanović, G. \& SAvić, L. 2013. Jezerski ostrakodi i prateci mekušci iz kupreškog polja, donji deo dinaridskog sistema jezera (Otnang) na visini od $1,150 \mathrm{~m}$. Zapisnici Srpskog geološkog društva 2011, 1-25.

Krstić, N., SAvić, L., Jovanović, G. \& Bodor, E. 2003. Lower Miocene lakes of the Balkan Land. Acta Geologica Hungarica 46, 291-299. DOI 10.1556/AGeol.46.2003.3.4

LARTET, E. 1837. Sur les débris fossiles trouvés à Sansan, et sur les animaux antédiluviens en général. Comptes-rendus hebdomadaires des séances de l'Académie des Sciences 5(12), 158-159.

LARTET, E. 1851. Notice sur la colline de Sansan, suivie d'une récapitulation des diverses espèces d'animaux vertébrés fossiles, trouvés soit à Sansan, soit dans d'autres gisements du terrain tertiaire miocène dans le bassin sous-pyrénéen. $45 \mathrm{pp}$. J.-A. Protes, Auch.

LinNAEUS, C. 1758. Systema naturae per regna tria naturae, secundum classes, ordines, genera, species, cum characteribus, differentiis, synonymis locis. Tomus 1. iii +824 pp. Laurentius Salvius, Holmiae.

Lozouet, P. 1985. Compléments à la Malacofaune Oligocène (Stampien) de Gaas (Bassin d'Aquitaine, France), 1. Mollusques Saumatres. Mededelingen van de Werkgroep voor Tertiaire en Kwartaire Geologie 22(3), 125-142.

Magrograssi, A. 1928. La fauna levantina di Coo e di Rodi. Atti della Società Italiana di Scienze Naturali e del Museo Civico di Storia Naturale in Milano 67, 249-264.
Malez, M. \& SlišKović, T. 1964. Neue Fundorte tertiärer Wirbeltiere in Bosnien und Herzegowina. Bulletin scientifique / Conseil des Académies de la RPF de Yougoslavie. sect. A, Sciences naturelles, techniques et médicales 9(1-2), 3-4.

Malez, M. \& SlišKović, T. 1965. O novim nalazima vrste Dinotherium bavaricum v. Meyer u ugljenokopu Repovica kod Konjica. Glasnik Zemaljskog muzeja Bosne i Hercegovine, Prirodne nauke 3-4, 7-23.

MaLez, M. \& SlišKović, T. 1976. Starost nekih naslaga ugljena u tercijaru Bosne i Hercegovine na osnuvi nalaza vertebrata. Geološki glasnik 21, 39-56.

Mandic, O., De Leeuw, A., Bulić, J., Kuiper, K.F., Krijgsman, W. \& JURIŠIĆ-POLŠAK, Z. 2012. Paleogeographic evolution of the Southern Pannonian Basin: ${ }^{40} \mathrm{Ar} /{ }^{39} \mathrm{Ar}$ age constraints on the Miocene continental series of northern Croatia. International Journal of Earth Sciences 101(4), 1033-1046. DOI 10.1007/s00531-011-0695-6

Mandic, O., De Leeuw, A., Vuković, B., Krijgsman, W., Harzhauser, M. \& KuiPeR, K.F. 2011. Palaeoenvironmental evolution of Lake Gacko (Southern Bosnia and Herzegovina): Impact of the Middle Miocene Climatic Optimum on the Dinaride Lake System. Palaeogeography, Palaeoclimatology, Palaeoecology 299, 475-492. DOI 10.1016/j.palaeo.2010.11.024

Mandic, O., Pavelić, D., Harzhauser, M., Zupanič, J., Reischenbacher, D., SAChSEnhofer, R.F., TADEJ, N. \& VRANJKOVIĆ, A. 2009. Depositional history of the Miocene Lake Sinj (Dinaride Lake System, Croatia): a long-lived hard-water lake in a pull-apart tectonic setting. Journal of Paleolimnology 41, 431-452. DOI 10.1007/s10933-008-9235-1

Meyer, H. v. 1831. Mitteilungen an geheimen Rath von Leonhard. Jahrbuch für Mineralogie, Geognosie, Geologie und Petrefaktenkunde 2, 296-297.

Milan, A., SAKAČ, K. \& ŽAGAR-SAKAČ, A. 1974. Katalog originala tipova vrsta pohranjenih u Geološko-paleontološkom muzeju u Zagrebu. 186 pp. Geološko-paleontološki muzej u Zagrebu, Zagreb.

MoJIĆEVIĆ, M. \& LAUŠEVIĆ, M. 1971. Osnovna geološka karta SFRJ 1:100.000. List Mostar K33-24. Savezni geološki zavod, Beograd.

MoJićević, M. \& Tomić, B. 1982. Osnovna geološka karta SFRJ 1:100.000. List Kalinovik K34-13. Savezni geološki zavod, Beograd.

Montfort, P.D. d. 1810. Conchyliologie systématique et classification méthodique de coquilles; offrant leurs figures, leur arrangement générique, leurs descriptions caractéristiques, leurs noms; ainsi que leur synonymie en plusieurs langues. Ouvrage destiné à faciliter l'étude des coquilles, ainsi que leur disposition dans les cabinets d'histoire naturelle. Coquilles univalves, non cloisonnées. 2. 676 pp. Schoell, Paris.

Neubauer, T.A., Harzhauser, M., Georgopoulou, E., Kroh, A. \& MANDIC, O. 2015c. Tectonics, climate, and the rise and demise of continental aquatic species richness hotspots. Proceedings of the National Academy of Sciences of the United 
States of America 112(37), 11478-11483.

DOI 10.1073/pnas.1503992112

Neubauer, T.A., Harzhauser, M., Georgopoulou, E., Mandic, O. \& KROH, A. 2014a. Replacement names and nomenclatural comments for problematic species-group names in Europe's Neogene freshwater Gastropoda. Zootaxa 3785(3), 453-468. DOI 10.11646/zootaxa.3785.3.7

Neubauer, T.A., Harzhauser, M., Kroh, A., Georgopoulou, E. \& Mandic, O. 2014c. The FreshGEN Database: Freshwater Gastropods of the European Neogene. Accessed at http://www.marinespecies.org/freshgen on 2015-08-26.

Neubauer, T.A., Harzhauser, M., Kroh, A., Georgopoulou, E. \& MANDIC, O. 2015a. A gastropod-based biogeographic scheme for the European Neogene freshwater systems. Earth-Science Reviews 143, 98-116. DOI 10.1016/j.earscirev.2015.01.010

Neubauer, T.A., Harzhauser, M. \& Pipík, R. 2015b. Upper Miocene endemic lacustrine gastropod fauna of the Turiec Basin: addressing taxonomic, paleobiogeographic and stratigraphic issues. Geologica Carpathica 66(2), 139-156.

DOI 10.1515/geoca-2015-0016

Neubauer, T.A., Mandic, O. \& Harzhauser, M. 2011. Middle Miocene Freshwater Mollusks from Lake Sinj (Dinaride Lake System, SE Croatia; Langhian). Archiv für Molluskenkunde 140(2), 201-237.

DOI 10.1127/arch.moll/1869-0963/140/201-237

Neubauer, T.A., Mandic, O. \& Harzhauser, M. 2013b. The Middle Miocene freshwater mollusk fauna of Lake Gacko (SE Bosnia and Herzegovina): taxonomic revision and paleoenvironmental analysis. Fossil Record 16(1), 77-96. DOI 10.1002/mmng.201300003

Neubauer, T.A., Mandic, O. \& Harzhauser, M. 2014b. A new melanopsid species from the Middle Miocene Kupres Basin (Bosnia and Herzegovina). The Nautilus 128(2), 51-54.

Neubauer, T.A., Mandic, O. \& Harzhauser, M. 2016. The freshwater mollusk fauna of the Middle Miocene Lake Drniš (Dinaride Lake System, Croatia): a taxonomic and systematic revision. Austrian Journal of Earth Sciences 108(2), 15-67. DOI 10.17738/ajes.2015.0013

Neubauer, T.A., Mandic, O., Harzhauser, M. \& Hrvatović, H. 2013a. A new Miocene lacustrine mollusc fauna of the Dinaride Lake System and its palaeobiogeographic, palaeoecologic, and taxonomic implications. Palaeontology 56(1), 129-156. DOI 10.1111/j.1475-4983.2012.01171.x

Neumayr, M. 1869. II. Beiträge zur Kenntniss fossiler Binnenfaunen. Jahrbuch der kaiserlichen und königlichen geologischen Reichsanstalt 19, 355-382.

Neumayr, M. 1880. V. Tertiäre Binnenmollusken aus Bosnien und der Hercegovina. Jahrbuch der kaiserlichen und königlichen geologischen Reichsanstalt 30(2), 463-486.

NeumaYr, M. 1883. Ueber einige tertiäre Süsswasserschnecken aus dem Orient. Neues Jahrbuch für Mineralogie, Geologie und Paläontologie 1883(2), 37-44.

Olivier, G.A. 1804. Voyage dans l'Empire Othoman, l'Égypte et la Perse, fait par ordre du gouvernement, pendant les six premières années de la République. Tome second. 466 pp. Agasse, Paris.
Pavlović, P.S. 1927. Donjopontiski mekušci iz okoline Beograda (s narocitim obzirom na fosilnu faunu okoline sela Vrcina). Sprska Akademija nauka, posebna izdanja 66 (Prirodnjacki i matematicki spisi 17), 1-121.

Poey, F. 1852. Introduccion a los Ciclostomas con generalidades sobre los moluscos gastropodos y particularmente sobre los terrestres operculados. Memorias sobre la Historia Natural de Cuba 1(8), 77-96.

RAFINESQUe, C.S. 1815. Analyse de la nature ou tableau de l'univers et des corps organisés. 223 pp. Privately published by author, Palermo.

RöSSNER, G.E. \& HeIsSIG, K. 1999. The Miocene Land Mammals of Europe. 515 pp. Verlag Dr. Friedrich Pfeil, Munich.

SAndBerger, C.L.F. 1870-1875. Die Land- und SüßwasserConchylien der Vorwelt. Livr. 1-3: pp. 1-96, pl. 1-12 (1870); livr. 4-5: pp. 97-160, pl. 13-20 (1871); livr. 6-8: pp. 161-256, pl. 21-32 (1872); livr. 9-10: pp. 257-352, pl. 33-36 (1873); livr. 11: pp. i-viii + 353-1000 (1875). C.W. Kreidel, Wiesbaden.

Schmid, S.M., Bernoulli, D., Fügenschuh, D., Matenco, L., Schefer, S., Schuster, R., Tischler, M. \& Ustaszewski, K. 2008. The Alpine-Carpathian-Dinaridic orogenic system: correlation and evolution of tectonic units. Swiss Journal of Geosciences 101, 139-183.

DOI 10.1007/s00015-008-1247-3

SofiLJ, J. \& Živanović, M. 1979. Osnovna geološka karta SFRJ 1:100.000. List Prozor K33-12. Savezni geološki zavod, Beograd.

SofilJ, J., Živanović, M. \& Pamić, J. 1980. Osnovna geološka karta SFRJ 1:100.000. Tumač za list Prozor K33-12. Savezni geološki zavod, Beograd.

Starobogatov, Y.I. 1970. Fauna mollyuskov i zoogeographicheskoye rayonirovaniye kontinentalnykh vo do emov zemnogo shara [The mollusk fauna and zoogeographical regionalisation of continental waterbodies of the Earth]. 372 pp. Nauka, Leningrad.

Stimpson, W. 1865. Researches upon the Hydrobiinae and allied forms: chiefly made from materials in the Museum of the Smithsonian Institution. Smithsonian Miscellaneous Collections $7,1-59$.

TARI, V. 2002. Evolution of the northern and western Dinarides: a tectonostratigraphic approach. European Geosciences Union Stephan Mueller Special Publication Series 1, 223-236.

DOI 10.5194/smsps-1-223-2002

TOuRnOuËr, R. 1875. Diagnose d'une Coquille fossile des terrains tertiaires supérieurs d'eau douce de l'île de Cos. Journal de Conchyliologie 23, 167.

Troschel, F.H. 1857. Das Gebiss der Schnecken, zur Begründung einer natürlichen Classification, 73-112. Nicolai, Berlin.

WAdE, C.M., Mordan, P.B. \& NAGGs, F. 2006. Evolutionary relationships among the Pulmonate land snails and slugs (Pulmonata, Stylommatophora). Biological Journal of the Linnean Society 87, 593-610. DOI 10.1111/j.1095-8312.2006.00596.x

Wenz, W. 1923-1930. Fossilium Catalogus I: Animalia. Gastropoda extramarina tertiaria. VII: 1863-2230 pp. (1926), 
VIII: 2231-2502 pp. (1928), IX: 2503-2886 pp. (1929a), X: 2887-3014 pp. (1929b). W. Junk, Berlin.

Wenz, W. 1938-1944. Gastropoda. Teil 1: Allgemeiner Teil und Prosobranchia, 1-1639. In Schindewolf, O.H. (ed.) Handbuch der Paläozoologie, Band 6. Verlag Gebrüder Bornträger, Berlin.

WiLlmann, R. 1981. Evolution, Systematik und stratigraphische Bedeutung der neogenen Süßwassergastropoden von Rhodos und Kos/Ägäis. Palaeontographica, Abteilung A 174, 10-235.

ŽAGAR-SAKAČ, A. 1981. Über die neogenen Unionazeen-Arten S. Brusina's. Palaeontologia jugoslavica 27, 1-26.

ŽAGAR-SAKAČ, A. 1986. Unio katzeri Brusina iz miocenskih slat- kovodnih naslaga Dalmacije (juzna Hrvatska). Rad Jugoslavenske akademije znanosti i umjetnosti 424, 167-189.

ŽAGAR-SAKAČ, A. 1987. O unionacejskoj fauni miocenskih slatkovodnih naslaga srednje Dalmacije. Rad Jugoslavenske akademije znanosti i umjetnosti 431, 69-91.

ŽAGAR-SAKač, A. 1990. O vrsti Unio čubranovići Brusina iz miocenskih slatkovodnih naslaga Lovče u Baniji, Središnja hrvatska. Rad Jugoslavenske akademije znanosti i umjetnosti 449, 251-260.

ŽAGAR-SAKAČ, A. \& SAKAČ, K. 1984. Nalazišta unionacejske faune neogenskih (miocenskih) naslaga Dalmacije (južna Hrvatska). Rad Jugoslavenske akademije znanosti i umjetnost $i$ 411, 209-230. 